\title{
Determinants of Multifactor Productivity: The Cases of the Main Latin American and Successful Asian Economies (1960-2015)
}

\author{
Wilman Arturo Gómez Muñoz ${ }^{1}$, Carlos Esteban Posada Posada ${ }^{2}$, Remberto Rhenals Monterrosa ${ }^{1}$ \\ ${ }^{1}$ Economics Department at Universidad de Antioquia, Medellín, Colombia \\ ${ }^{2}$ School of Economics and Finance at Universidad EAFIT, Medellín, Colombia \\ Email:wilman.gomez@udea.edu.co,cposad25@eafit.edu.co,rrhenals54@gmail.com
}

How to cite this paper: Gómez Muñoz, W. A., Posada Posada, C. E., \& Rhenals Monterrosa, R. (2020). Determinants of Multifactor Productivity: The Cases of the Main Latin American and Successful Asian Economies (1960-2015). Theoretical Economics Letters, 10, 803-833.

https://doi.org/10.4236/tel.2020.104049

Received: June 16, 2020

Accepted: August 2, 2020

Published: August 5, 2020

Copyright $\odot 2020$ by author(s) and Scientific Research Publishing Inc. This work is licensed under the Creative Commons Attribution International License (CC BY 4.0).

http://creativecommons.org/licenses/by/4.0/

\begin{abstract}
The objective of this paper was to explain the greater or lesser growth rate of total factor productivity, TFP, in the main East Asian and Latin American economies between 1960 and 2015. We found econometric evidence favorable to this hypothesis: the increase in public consumption expenditures, given the evolution of other factors, reduces the TFP. Other results of the econometric exercise, those that are related to hypothetical positive effects of public investment and imports on TFP were not as robust or as reliable as we would have expected.
\end{abstract}

\section{Keywords}

Per Capita GDP's Growth Rate, Total Factor Productivity, Physical Capital, Human Capital, Public Consumption, Public Investment, Imports, Panel Cointegration

\section{Introduction}

Between 1950 and 2015, GDP per capita in Latin America (set of 7 economies of the region) went from 2662.5 to 8515.1 in 1990 international dollars ${ }^{1}$; the GDP per capita of "Asia" (set of 9 successful economies of Asia) ${ }^{2}$ went from 565.6 to

\footnotetext{
${ }^{1}$ i.e. measured in the so-called "1990 International Geary-Khamis dollars." Data for the years 2009-2015 were obtained by connecting the Maddison Database 2010 series (with information up to 2008) with the growth rates of GDP per capita (rgdpnapc) and the population of Maddison Project Database 2018.

${ }^{2}$ What we call "Latin America" in this document comprises Argentina, Brazil, Chile, Colombia, Mexico, Peru and Venezuela. "Asia" includes China (mainland), Hong Kong, India, Indonesia, Malaysia, Singapore, South Korea, Taiwan and Thailand. An important precision is needed about Hong Kong and Taiwan: although Hong Kong is officially a China's special administrative region and the political status of Taiwan is still uncertain (although reclaimed by China), in the economic literature and in some international databases (PWT, TED and Maddison Database for example) they are often considered as independent or autonomous economies. In this work, we follow such consideration.
} 
8018.6, also measured in 1990 international dollars. Thereby, whereas in 1950 the GDP per capita in Asia was only 21.2\% of Latin American GDP; in 2015, both of them were almost equal (around 94.2\%).

The eradication of the per capita income gap between these two regions derived from the extraordinary dynamism of Asia and the weakening of the economic growth of Latin América; mainly, since the beginning of the 1980s. In fact, whereas between 1950 and 1980 the GDP growth per capita was similar (2.7\% annual average) in both regions, during the three and a half following decades, the economic growth of Latin America and Asia was 1.1\% and 5.4\% annual average, respectively. From 1950 to 2015, the average annual GDP growth rate per capita was $1.8 \%$ in Latin America and $4.2 \%$ in Asia.

This aggregate behavior of both regions hides, in one of the cases, important differences in their national economies' performances; at least, when it is considered the small economies group versus the large economies group. In the case of Latin America, except for Chile, the reduction of the growth rates between these two long periods (1950-2015) of time was widespread, although this fall was much higher in the largest economies (the GDP annual growth rate per capita decreased from $3.6 \%$ to $1 \%$ ) than in the small economies (from $1.6 \%$ to $1.2 \%$ per annum). ${ }^{3}$

In contrast, in the case of Asian economies, the growth dynamics between these two groups (large and small economies) was quite different ${ }^{4}$ : the per capita income of the small economies group grew faster than the one of the big economies group from 1950 to 1980 (4\% and 2.3\% per annum, respectively), whereas between 1980 and 2015, this behavior turned upside down (4\% and 5\% per annum, in the given order). Throughout the six and a half decades analyzed, the per capita income growth of both economies groups is almost the same (4\% in the small economies group and $4.2 \%$ in the big economies group).

This brief description about long-term performances in Latin America and Asia allows us to affirm that their most outstanding aspects were, on one side, the low dynamism of the first region and the extraordinary growth of the second one; and, on the other side, the weakening (in one of the cases) and the acceleration of growth (in the other case) registered in the two regions in the last 35 years in relation with the three previous decades.

What is behind those important differences in economic growth of these two

${ }^{3}$ The economies that have consolidated as the largest in Latin America in terms of both population and GDP are Brazil and Mexico. In fact, their share in the GDP of the seven economies under consideration increased from $45.5 \%$ in 1950 , reaching a peak of $65.5 \%$ in 1989; it then declined slightly to $60.4 \%$ in 2015. Argentina's economy, which for most of the 1950s was as large as those of Mexico and Brazil because of its relative importance in regional GDP, has recorded a significant decline since then, as has its population, although to a lesser extent. A similar behavior is observed in Venezuela in terms of the importance of its economic activity.

${ }^{4}$ The large economies of Asia are China and India, although the relative importance of the latter in the GDP of the nine economies considered has declined sharply. Due to this behavior of India, the joint participation of these two countries has increased from approximately $80 \%$ in the 1950 s to just under $70 \%$ in the 1990 s, and has again reached $80 \%$ in recent years. The other economies are very far apart in terms of both population and GDP. 
regions?

With this article, we seek to partly answer this question. With respect to this, in Section 2, we present our hypothesis and we reference the publications where such hypotheses come from. In Section 3, we explain the strategy we developed in the econometric work and its results. In Section 4, we summarize the work and we present our conclusions. As annex, we reported our measurements of variables and statistical sources used; there, we describe (and justify) the empirical work we did to build some of the variables used in the econometric exercises we employed to prove our hypothesis; and we present the results of diverse econometric tests.

\section{Literature and Hypothesis}

The literature has pointed that in per capita income differences among countries and their long-term economic growth rates are mainly explained because of the levels and the dynamic of multifactor productivity of economy or, in other words, the efficiency of countries to use their production factors available.

Thus, after taking into account the accumulation of both human and physical capital, there is "something else" that represents the biggest part of the differences between per capita income levels and economic growth rates among countries. Consequently, the core problem facing analysts in understanding economic development and economic growth is not understanding the process through which an economy makes increase both its saving and physical capital accumulation rates, but understanding "something else" plays an outstanding role for explaining differences in long-term economic performance among countries (Easterly \& Levine, 2001). ${ }^{5}$ Generally, economists use the term "total factor productivity", TFP to refer to that "something else".

In spite there is/In spite of relative consensus among academics on the importance and TFP measurements (or "aggregate productivity" or "multifactor productivity"), no consensus exists on its determinants. Actually, the diverse models of endogenous growth are based on this hypothesis about different TFP growth engines. This evinces very different conceptions of TPF.

Fernández-Arias (2017) points that per capita GDP growth gaps and TFP of Latin America, in relation with the rest of the world, seem larger and more systematic. Whereas accumulation of factors in Latin America has been aligned with the rest of the world, its economic growth is different because of its lower growth of TFP.

Figure 1 represents TFP evolution in both regions. As can be seen, in Latin America this variable increased rapidly in the $1960-1980$ period $(2.1 \%$ per annum); subsequently, it was registered a sustained reduction ( $-1.8 \%$ per annum). For its part, this variable increased steadily in Asia, slowly in the first two decades ( $0.4 \%$ per annum), but rapidly from the beginning of the 1980 decade $(2.7 \%$

${ }^{5}$ As these authors point out, this does not mean that the accumulation of factors is not important in general or that it is not critical for some countries at specific times. 


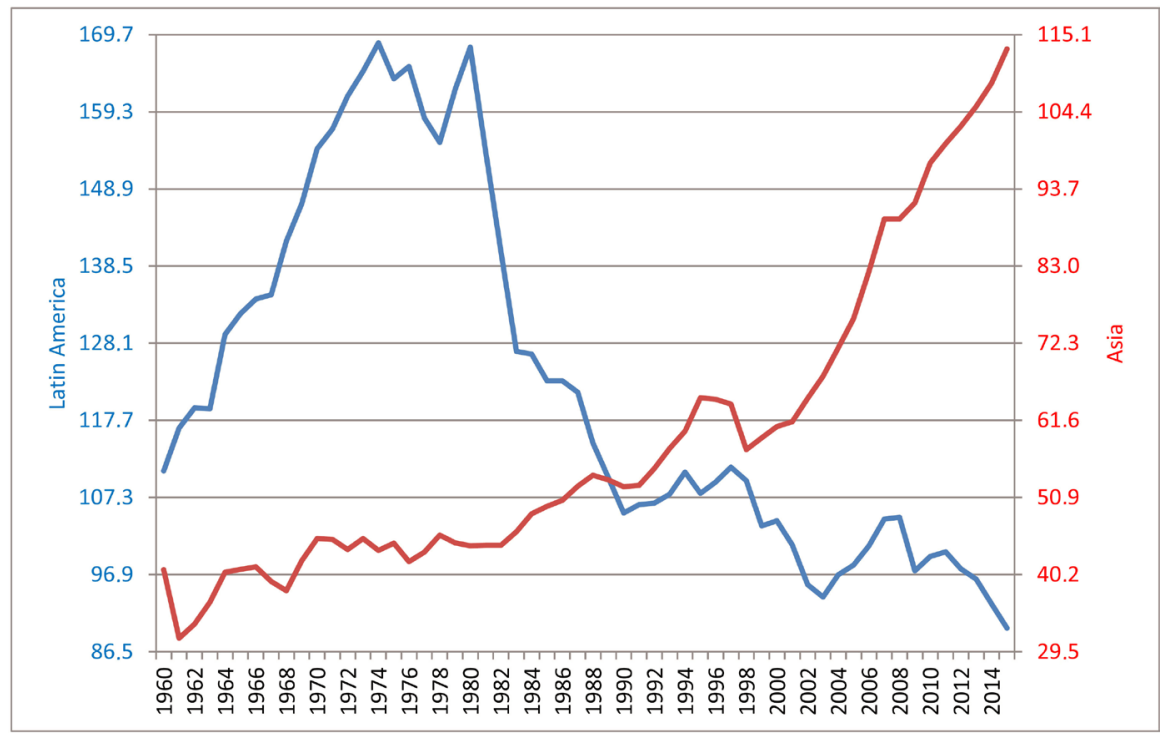

Source: Penn World Tables (PWT 9.0) except for Argentina, whose source is mentioned in Annex 1. Calculations by authors.

Figure 1. Multifactor productivity (TFP; indices in Latin America and Asia 1960-2015 $(2011=100))$.

per annum). It also can be observed that this aggregate productivity behavior went hand to hand with GDP evolution per capita in both regions, at least with regard to long term tendencies. ${ }^{6}$

Between 1960 and 1980, the growth of Latin American productivity was boosted by the larger economies of the region (3.3\% per annum), whereas the growth of the smaller economies set was low ( $0.5 \%$ per annum). For its part, the fall in productivity for the three and a half following decades (1980-2015) was generalized, but it was larger in the first ones $(-2.1 \%$ per annum) than in the second ones $\left(-1.1 \%\right.$ per annum). ${ }^{7}$ It can be said that, in the $1960-2015$ period, Latin American productivity was stagnant $(-0.4 \%$ per annum $){ }^{8}$

In the Asian case, productivity growth between 1960 and 1980 was driven by

${ }^{6}$ Although GDP per capita and multifactor productivity are based on different measures (the former in purchasing power parity or 1990 international dollars and the latter obtained from national accounts figures at constant 2011 prices of the respective economies converted to 2011 dollars), this difference does not create major problems of comparison in terms of their trends and growth rates. In fact, the ratios of Asia's per capita GDP to Latin America's, measured in both forms (1990 international dollars and in constant 2011 prices of the economies converted to 2011 dollars), show the same pattern (almost stagnation in the period 1950-1980 and rapid increase thereafter), although the percentage values differ to some extent. These differences can be explained by the prices used and the choice of the base year.

${ }^{7}$ In fact, the peak in productivity for the region in 1980 is explained by Brazil, Colombia, and Mexico, since for the other economies it occurs in 1970 (Venezuela) and 1974 (Argentina and Peru). In these countries, productivity clearly drops afterwards. Although the behavior of productivity in Chile follows a different pattern since the early 1970s, a stagnation is observed between 1980 and 2015. However, between 1985 and 2015, it records an increase amidst fluctuations of medium duration. It also shows that Chile does not escape from the pattern of low productivity performance typical of Latin America.

${ }^{8}$ For larger economies the growth rate was calculated by the authors at $-0.2 \%$ per annum, and in smaller economies $(-0.5 \%$ per annum). 
small economies (3.4\% per annum), whereas productivity acceleration was driven by large economies between 1980 and 2015 (3.1\% per annum). ${ }^{9}$ This relief explains the important growth of Asian productivity during the five and a half decades under analysis (1.9\% per annum).

Economists have pointed to a set of determinant variables of aggregate productivity behavior, among which international trade openness and the importance of public sector in economy can be highlighted (Loayza, Fajnzylber, \& Calderón, 2005). Before describing the evolution of these variables in both regions, a clarification deems necessary: as opposed to Latin America, aggregate data from Asia conceal marked heterogeneities among its economies, either as GDP percentages or in per capita terms.

Trade openness directly influences total productivity of factors through, at least, two channels: on the one hand, by means of technological innovation diffusion and improvements in managerial practices, since they reinforce the interaction between national enterprises and external enterprises as well as markets; and, on the other hand, by virtue of sparse incentives that local enterprises receive when openness is absolute or almost absolute, in order to perform unproductive rentier activities and anticompetitive practices (Loayza, Fajnzylber, \& Calderón, 2005). Particularly, the "new" growth theories have given a persuasive support to the proposition that openness affects growth positively, since they argue, for instance, that countries more open to the rest of the world have a higher capacity to absorb the new technological advances generated in leading nations (Edwards, 1998).

In fact, a great deal of empirical evidence shows a positive relation between economic growth and international openness. This reflects a virtuous circle in which a larger openness drives to a larger growth, which generates more commerce. ${ }^{10}$ In a review of empirical evidence on the effects of trade liberalization on business innovation, Shu and Steinwender (2018) have concluded that trade liberalizations, for the case of emerging countries, seem to stimulate productivity and innovation.

Figure 2 shows the evolution of the openness degree of Latin American and Asian economies under consideration, measured by participation of imports in GDP. It can be seen from the figure that from the 1950s to the end of the 1980s, there was an obvious steady downward trend. ${ }^{11}$ Since then, it registers an increase practically sustained to reach levels around 21\% of GDP in 2014. This greater openness of Latin American economy was associated to the agenda of

${ }^{9}$ In the first period (1960-80), productivity growth in the large economies was $-0.6 \%$ per year, due to the sharp drop in productivity in China. In the second period (1980-2015), productivity growth in the group of small economies was $1.4 \%$ per year.

${ }^{10}$ Besides, international trade allows countries to exploit their comparative advantages and to expand their potential markets; it leads to a greater specialization and allows national companies to make the most of economies of scale, which generates productivity gains (Lederman, 1996, cited by Loayza, Fajnzylber and Calderón, 2005).

${ }^{11} \mathrm{~A}$ discussion about different openness measures and their relation with economic performance of countries, as can be seen in Pritchett (1996). 


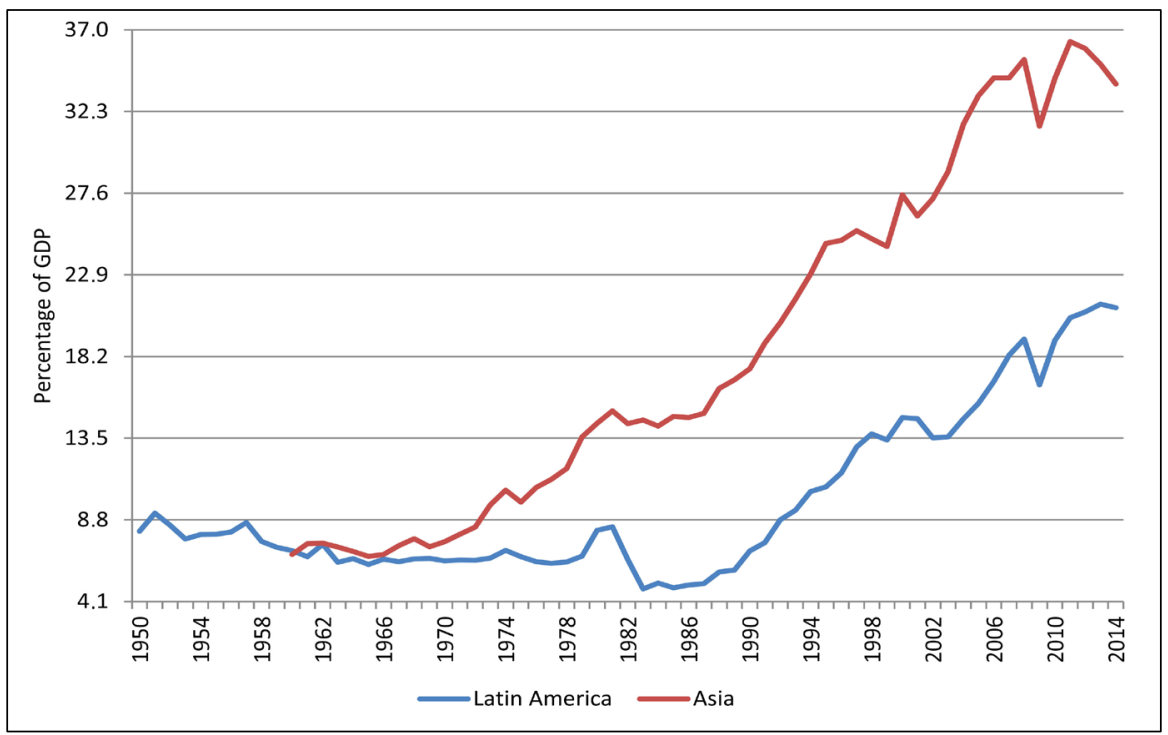

Note: Import and GDP figures are in real terms. Data used for China corresponds to "Alternative China”. Source: Penn World Table 9.0. Calculations by authors.

Figure 2. Evolution of the degree of openness in Latin America and Asia, 1950-2014.

structural reforms onset in the region, mainly since the 90s. Two important components of this agenda were trade liberalization, in other words, a deeper trade integration with world economy, and a reduction of obstacles and disincentives to foreign direct investment (Ros, 2014).

In terms of external openness, the course of economies hereby considered is different. In effect, its opening process started in the beginning of 1970s and, clearly, it has been a region much more open to international trade than Latin America. It can be observed that the openness degree of the regions set was practically similar to the Latin American set in the 60s (around 7\% of GDP); since then, it grew up to $35 \%$ during the last years. It is worth noting that this aggregate behavior hides heterogeneity between these economies: Hong Kong and Singapore are fully open economies, followed by Malaysia; whereas China and India are much less open.

However, despite these significant differences in openness degrees of Asian economies, they all moved in the same direction. In particular, those less open (China and India) than those of Latin America in the 1960s have recently become a little more open than the Latin American group.

On the other hand, the differences in openness degrees between Latin American countries are substantially smaller, this reflecting convergence between institutional structure and economic policy in the region. This can be explained by the fact that in the first decades of the post-war period, industrialization was driven by the State and focused on the domestic market, and subsequently derived from the process of economic liberalization (Ros, 2014).

Figure 3 shows the openness of the two regions as measured by real per capita imports. In Latin American countries, the openness degree was low and stable 


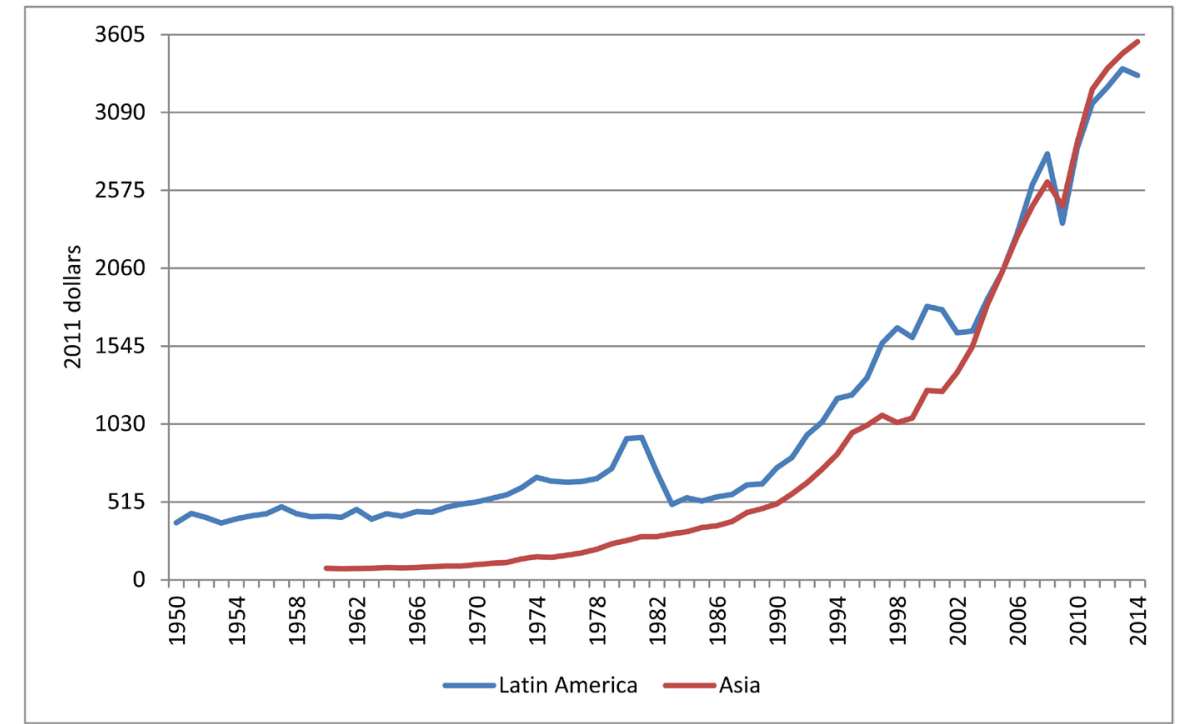

Source: Penn World Table 9.0. Calculations by authors.

Figure 3. Real per capita imports in Latin America and Asia, 1950-2014.

until the end of the 1980s but increased thereafter. The openness degree of the Asian economies group is not quite different from that of Latin America, mainly because of the low levels of openness of the largest Asian economies (China and India), as well as that of Indonesia. However, real per capita imports have increased significantly since the early 1990s.

Other economies (Singapore and Hong Kong) have been historically rather open, at least in the period analyzed; or they registered a strong opening process starting from very low initial levels (South Korea and Thailand) or relatively low ones (Taiwan and Malaysia). These differences explain the high values of real imports as a percentage of GDP, or in Asian per capita terms, when calculated as the arithmetic average of the economies.

With regard to the importance of the public sector, it should be noted that while the government may play a beneficial role in the economy, it may also entail a heavy burden. This occurs when the government imposes high taxes on businesses, uses these revenues to sustain ineffective public programs and an inflated bureaucracy, distorts market incentives, and interferes negatively in the economy by assuming roles that are more appropriate for the private sector (Loayza, Fajnzylber, \& Calderón, 2005). Akcigit et al. (2018) and Cai et al. (2018) have demonstrated, with statistical evidence, the negative effects of taxes on companies and innovators in innovating activities, which generates, sooner or later, higher multi-factor productivity.

The measure generally used to determine the government's weight in the economy is the ratio of government consumption to GDP. Although not all public consumption can be considered as an obstacle to growth (for instance, expenditure on health, education, and police), much of the government's current (or consumer) expenditure has no clear social return and is mainly spent on bu- 
reaucratic expenses (Loayza, Fajnzylber, \& Calderón, 2005). A relevant distinction between consumption expenditures that are useful and those that are not useful for economic growth cannot be made, due to the lack of consistent data on these expenditure categories for the sample of selected economies. In any case, according to Barro and Lee (1994), public spending (consumption) can be a source of distortions in private decisions, thus negatively affecting productivity. ${ }^{12}$

One of the mechanisms through which the expansion of public spending can have a long-term depression effect on multifactorial productivity is to increase the opportunity cost of the material and human resources private companies can devote to projects with long-term effects, and which refer to what is called 'technical change' in a broad sense. By assuming that these resources have an alternative use, they should be devoted to immediate production in order to meet the demand induced by greater public spending. Posada (2015) has illustrated this possibility through an economic growth model marked by a specific factor: an endogenous technical improvement associated to the growing use of material and human resources with an opportunity cost similar to the one mentioned earlier. This reflection contributes to the foundation of our hypothesis on the negative effect of increased public consumption on TFP.

The evolution of the State size in the two regions has been clearly different. In Latin America, the share of public consumption in GDP remained virtually stagnant in the first three decades examined (1950-1980), if we consider the aggregate behavior of the countries in the region. In the following decades, it increased rapidly and steadily (Figure 4). This increase was virtually general for all

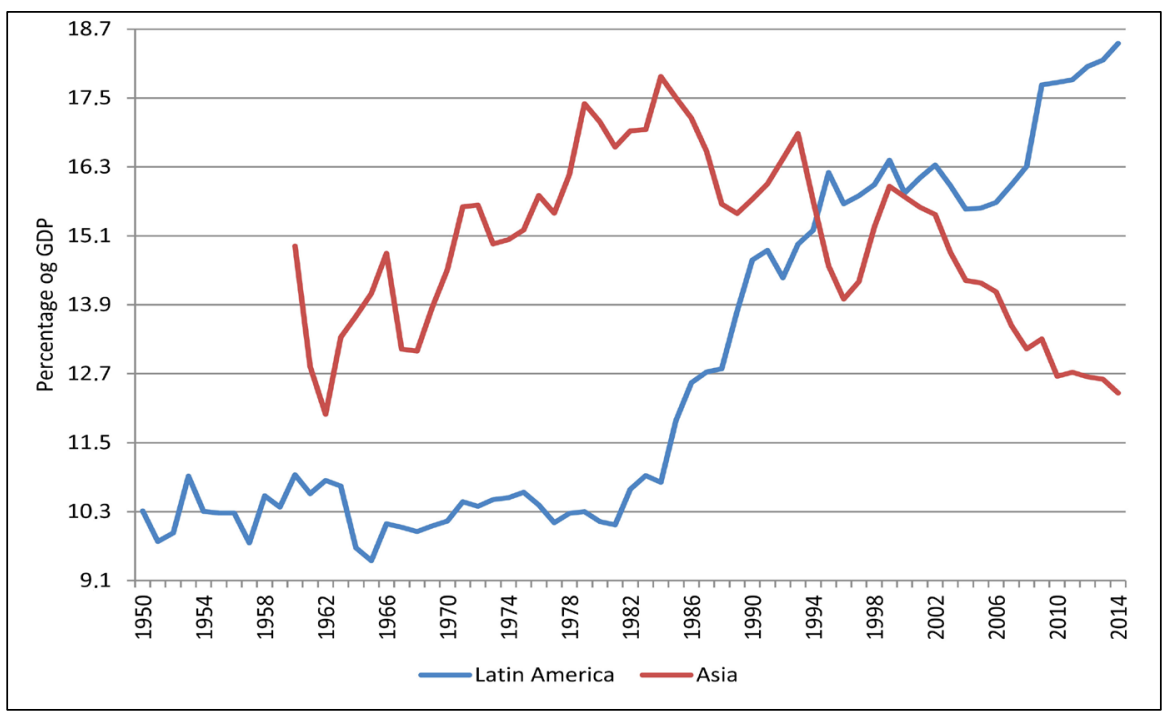

Source: Penn World Table 9.0. Calculations by authors.

Figure 4. Evolution of real public consumption expenditure/real GDP in Latin America and Asia, 1950-2014.

${ }^{12}$ The distortions associated with increasing public consumption may reflect those corresponding to government activities themselves (including the effects of political corruption) and also the adverse effects associated with distorting financing of public spending. 
the countries.

In the case of Asian economies, the size of the State increased until the mid-1980s and then declined sharply. This initial increase was due to the enormous public consumption share of in the GDPs of Taiwan and South Korea, by virtue of the large military expenditure. Subsequently, the size of their governments returned to the pattern displayed by the Asian economies in this analysis. In summary, the public consumption share of GDP in Latin America was lower than in Asia until the mid-1990s and thereon higher.

Moreover, in the case of Latin America, there has been a sustained increase in real public consumption per capita over the long term, albeit in the midst of medium-term accelerations and decelerations (Figure 5). In the group of Asian economies, real per capita public consumption also increased steadily (Figure 5), although its levels are much lower than those of Latin America.

The relationship between public investment and growth has been the subject of broad debate since, at least, the work of Aschauer (1989), which can be considered the starting point of the main branch in the literature on this subject (De la Fuente, 2010). ${ }^{13}$ Public investment can expand an economy's productive capacity, by increasing both the amount of resources available and the productivity of existing resources.

Various channels have been identified in the literature through which public investment can have positive effects on economic growth. Firstly, the public

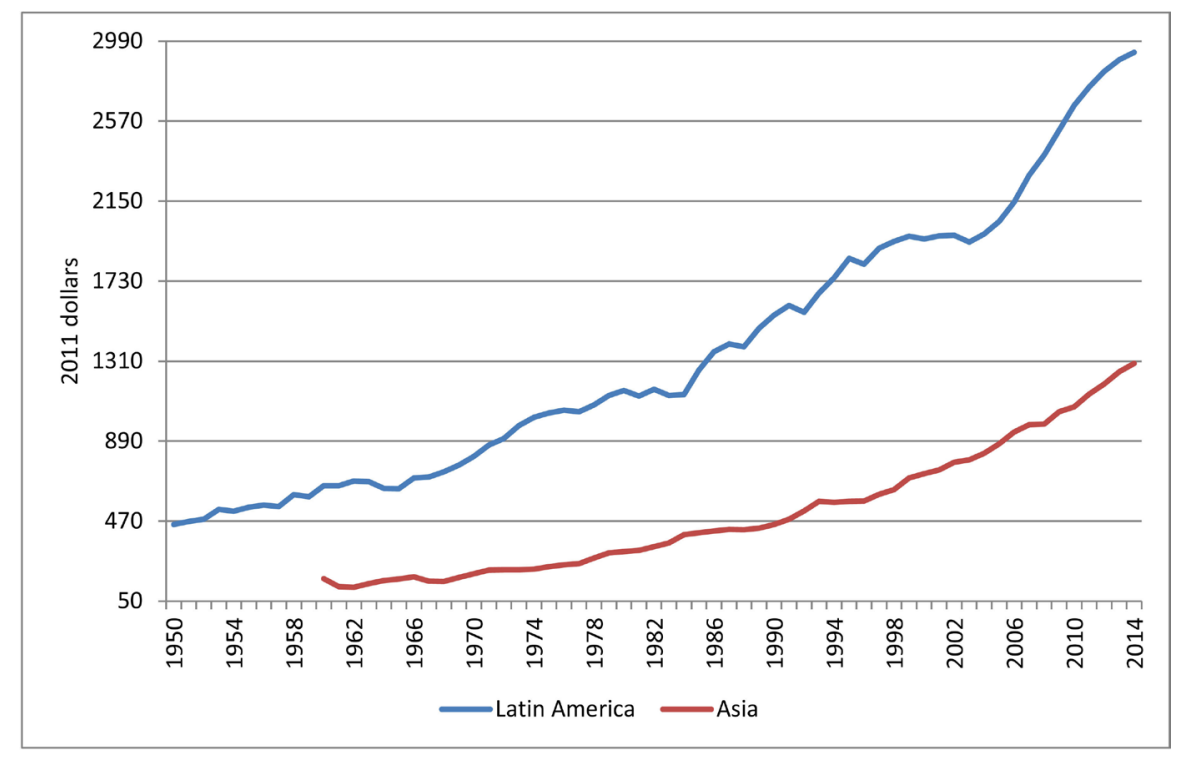

Source: Penn World Table 9.0. Calculations by authors.

Figure 5. Evolution of real public consumption expenditure per capita in Latin America and Asia, 1950-2014.

${ }^{13}$ The argument related to the efficiency of public investment seems to gain relevance in current debates. This efficiency depends on the sensitivity of the product (in the short and long term) to productive investment and the public decision processes in terms of project selection, implementation and monitoring. 
sector capital can be considered as something that must be incorporated into the production function as an additional factor. Secondly, public investment can also increase the willingness of the private sector to make further investments (crowding-in effect). ${ }^{14}$ And finally, public investment can have effects on productivity due to externalities, increasing returns to scale and cost reductions (Straub, 2008).

Despite the many theoretical approaches that attempt to substantiate the causal relationship between public investment and economic growth, the empirical results on these effects are unclear, and many consider it as unproductive (Arslanalp, Bornhorst, \& Gupta, 2011). Although the potential role of public infrastructure in improving productivity has been very prominent in recent years, the empirical evidence has been mixed at best (La Ferrara \& Marcellino, 2000; Arslanalp, Bornhorst, Gupta, \& Sze, 2010). ${ }^{15}$ However, some relatively recent studies (The World Bank, 2007, for example) conclude that public spending on infrastructure, education and health has positive effects on growth. The report of the World Bank Commission on Growth and Development (2008) points out that fast-growing countries have a high level of public investment, $7 \%$ or more of GDP (Arslanalp, Bornhorst, \& Gupta, 2011).

Figure 6 shows the evolution of public investment as a percentage of GDP in

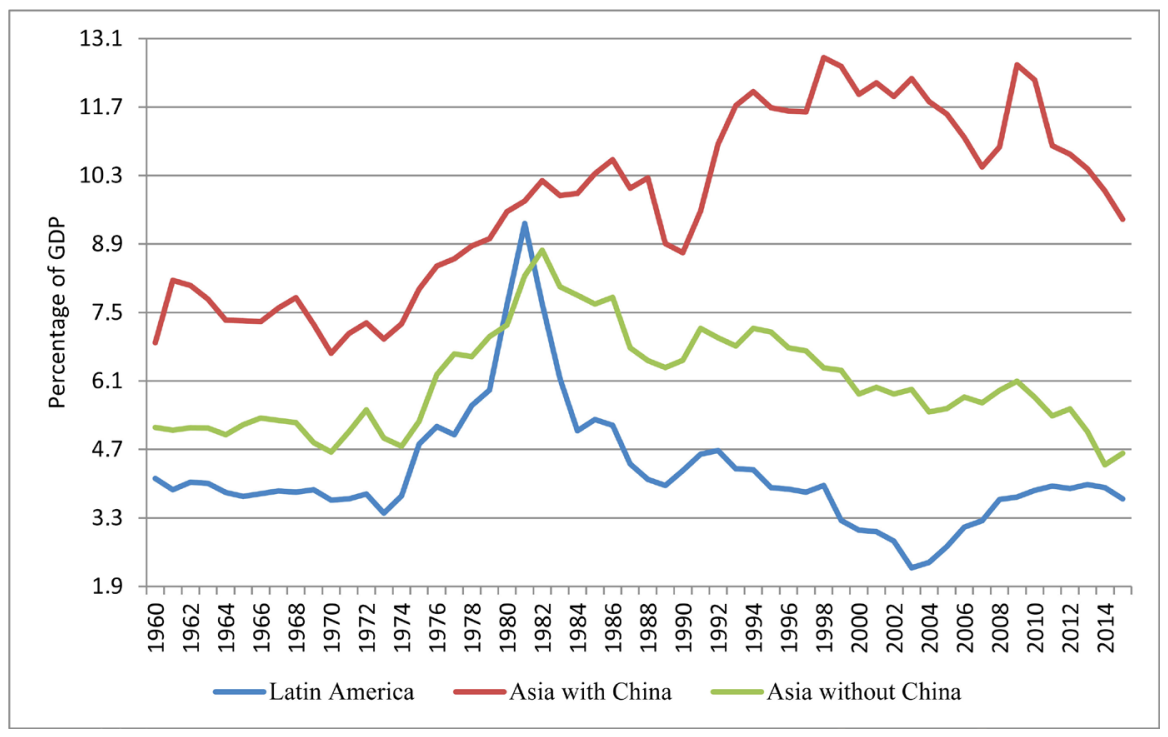

Source: FMI (2016), Fiscal Affairs Department Investment and Capital Stock Dataset, 1960-2015.

Figure 6. Real share of public investment in GDP in Latin America and Asia, 1960-2015.

\footnotetext{
${ }^{14}$ The relationship between public and private investment is characterized by two opposite forces: on the one hand, public capital can increase productivity of private capital, by increasing its return rate and inducing a higher investment. On the other hand, from the perspective of the investor, public capital works as a substitute for the private capital and crowds out private investment (Munnell, 1992). Moreover, the likely positive effects of public infrastructure are significantly reduced as their financing ways are considered.

${ }^{15}$ This article reviews the results of a large part of the literature on the relationship between capital or public investment and economic growth published between the mid-1990s and the middle of the following decade.
} 
real terms for the economies considered in Latin America and Asia. As can be seen, public investment in Latin America has averaged close to $4 \%$ of GDP, amidst fluctuations of varying intensity. In the case of Asian economies, it seems appropriate to show the evolution by including and excluding China. Figure 6 also illustrates the great importance of public investment in China, mainly since the early 1980s. In fact, the upward trend in the Asian public investment rate over these five and a half decades is explained by China.

Figure 6 shows the real public investment rate as GDP percentages for these economies. While the Asian economy, including China, shows a marked upward trend for the whole period, the Asian economies, without China, and Latin America show a growing pattern until the 80s, which changes to a decline pattern until 2015. It can also be observed that, when excluding China, the real share of public investment in GDP was lower and presented a clear decline since the early 1980s. In every case, it is clear that the relative importance of public investment has been greater in the group of Asian economies than in Latin American countries. However, this difference seems to be a manifestation of the gap in the factor accumulation rate between the two regions, which is, as Fernandez-Arias (2017) indicates, more of a peculiarity in East Asian development than a Latin American weakness.

Real public investment per capita in Latin America rose sharply in the 1970s. Then, amidst slight fluctuations, it contracted dramatically during the debt crisis of the 1980s until the beginning of the last decade, when it rose sharply again (Figure 7). This evolution was similar to that experienced by the share of public investment in GDP.

Real public investment per capita in Asia shows a clear increasing trend, mainly since the 1990s, due to its strong expansion in China. As a result, Asian

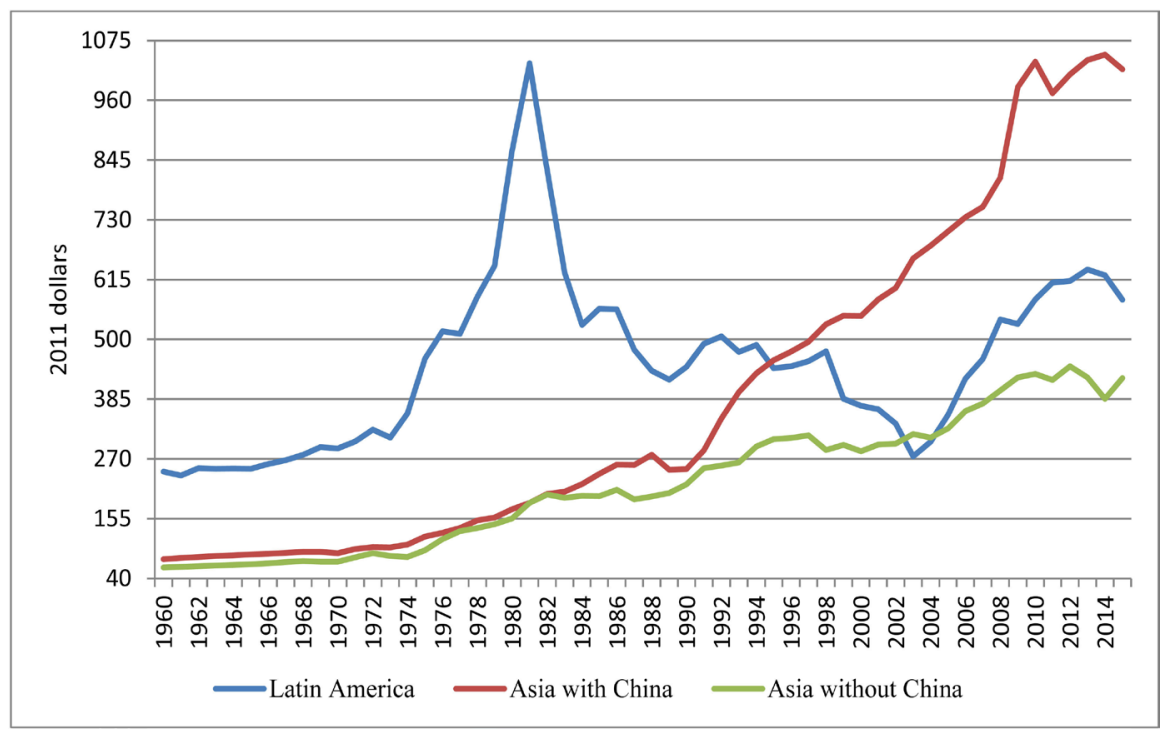

Source: FMI (2016), Fiscal Affairs Department. Investment and Capital Stock Dataset, 1960-2015.

Figure 7. Real public investment per capita in Latin America and Asia, 1960-2015. 
public investment (including China) per capita has been above that of Latin America since the second half of the 1990s (Figure 7). In contrast, when excluding China, public investment per capita has also been increasing, but at a historically lower rate than in Latin America.

\section{The Econometric Exercise and the Results}

Based on the previously discussed hypotheses, we proposed to estimate a panel cointegration model (data from a set of economies over time), which permits to assess the hypothetical long-term relationships between the dependent variable (multifactorial productivity of each country $i$ in each period $t$ of the time horizon) and the following explanatory variables: public spending (public consumption), public investment, imports and exports, by expressing the explanatory variables as percentages of GDP or in per capita terms (each variable for each country in each period). ${ }^{16}$ Evidence of cointegration between these last two variables raised a problem since introducing both of them into a model would generate a problem of redundant variables. Therefore it has been relevant to introduce only one of them. In this case, imports are used as the openness indicator of an economy.

Several panel data unit root tests were generally favorable to the existence of stochastic tendency (panel). The first and second generation conventional tests have supported this behavior (Breitung \& Pesaran, 2005; Hurlin \& Mignon, 2007), as well as the PANIC tests (Bai \& Ng, 2002, 2004, 2010; Pesaran, 2007), which show the existence of a panel unit root caused by the presence of at least one common factor that leads to such behavior in the series of the group of economies analyzed (Annex 5 shows the results of these tests). ${ }^{17}$

Annex 1 (Table A.1.1) presents the results of the import/export cointegration tests (as percentage of GDP), as well as those of the cointegration tests between TFP and its [assumed] determining variables as proportions of GDP and in per capita terms within models with a deterministic trend (Table A.1.2).

The cointegration equation to be estimated within the "cointegration and error correction vector" (ECV) with explanatory variables measured as percentage of GDP is as follows:

$$
\log \left(T F P_{i t}\right)=\beta_{0}+\beta_{1} \log \left(G G D P_{i t}\right)+\beta_{2} \log \left(I G G D P_{i t}\right)+\beta_{3} \log \left(M G D P_{i t}\right)+\beta_{4} t
$$

And with per capita variables, it is as follows:

$$
\log \left(T F P_{i t}\right)=\beta_{0}+\beta_{1} \log \left(G_{i t}\right)+\beta_{2} \log \left(I G_{i t}\right)+\beta_{3} \log \left(M_{i t}\right)+\beta_{4} t
$$

Table 1 shows the results of the cointegration exercise for the proposed models considering the 16 selected economies, i.e. including China. In all the esti-

\footnotetext{
${ }^{16}$ The construction of the dependent variable (TFP) in this work makes it inadequate to include the variable "human capital" or level of education among the explanatory variables in the equation to be estimated.

${ }^{17}$ An application of the PANIC tests for the Japanese economy is found in Shibamoto, Tsutsui, and Yamane (2016). Conventional first and second-generation tests are in R modules that are available on the internet: Croissant and Millo (2008), Kleiber and Lupi (2011), Lupi (2011) and Bronder (2015).
} 
mated models (columns A and B), the signs of the estimated coefficients for public spending and public investment are the expected, negative and positive respectively, as is the proxy for economic openness. ${ }^{18}$ For the variables as percentage of GDP (column A), the public spending coefficient (public consumption/GDP) is significant at certain conventional levels of significance. With respect to the public investment coefficient, some relaxation of the criteria would be required in order to reject the null hypothesis: $\mathrm{Ho}=0$. On the other hand, the rate of imports (imports/GDP) and the deterministic trend were not significant. In contrast, for variables in per capita terms (column B), the estimated coefficients are significantly different from zero for conventional significance levels for all

Table 1. Estimation results of cointegration models including China.

\begin{tabular}{|c|c|c|}
\hline \multicolumn{3}{|l|}{ Dependent variable: Log TFP } \\
\hline Independent variable: & A. Percentage of GDP & B. Per capita \\
\hline Log (public consumption): $L G$ & $\begin{array}{l}-0.690066^{*} \\
{[-4.19086]}\end{array}$ & $\begin{array}{l}-0.593109^{*} \\
{[-3.75748]}\end{array}$ \\
\hline Log (public investment): $L I G$ & $\begin{array}{c}0.147636 \\
{[1.44583]^{\star \star * \star}}\end{array}$ & $\begin{array}{c}0.280652^{* *} \\
{[2.39343]}\end{array}$ \\
\hline Log (imports): $L M$ & $\begin{array}{c}0.020417 \\
{[0.25688]}\end{array}$ & $\begin{array}{c}0.173842^{* * *} \\
{[1.93741]}\end{array}$ \\
\hline Trend (initial year 1960) & $\begin{array}{l}-0.000148 \\
{[-0.38153]}\end{array}$ & $\begin{array}{l}-0.000383 \\
{[-1.05744]}\end{array}$ \\
\hline Constant & 5.960275 & 5.778675 \\
\hline Determinant resid covariance (dof adj.) & $4.08 \mathrm{E}-09$ & $3.89 \mathrm{E}-09$ \\
\hline Determinant resid covariance & $3.97 \mathrm{E}-09$ & $3.71 \mathrm{E}-09$ \\
\hline Log likelihood & 3389.438 & 3353.193 \\
\hline Akaike information criterion & -7.925562 & -7.952387 \\
\hline Schwarz criterion & -7.763365 & -7.696891 \\
\hline \multicolumn{3}{|l|}{ Adjustment coefficients } \\
\hline alpha 1 & $\begin{array}{l}-0.032384^{\star} \\
{[-6.92493]}\end{array}$ & $\begin{array}{l}-0.025891^{*} \\
{[-6.59271]}\end{array}$ \\
\hline alpha 2 & $\begin{array}{l}-0.004961 \\
{[-1.03658]}\end{array}$ & $\begin{array}{l}-0.020946^{\star} \\
{[-5.35026]}\end{array}$ \\
\hline alpha 3 & $\begin{array}{l}0.017037 \\
{[1.59783]}\end{array}$ & $\begin{array}{l}-0.002611 \\
{[-0.27082]}\end{array}$ \\
\hline alpha 4 & $\begin{array}{l}-0.000177 \\
{[-0.01920]}\end{array}$ & $\begin{array}{c}-0.018276^{* *} \\
{[-2.01146]}\end{array}$ \\
\hline
\end{tabular}

Note: The $t$-values are in square brackets. The significance levels of $1 \%, 5 \%, 10 \%$ and $20 \%$ are indicated by one, two, three and four asterisks, respectively.

\footnotetext{
${ }^{18}$ Moderate estimates of public spending inefficiencies (inefficiencies in procurement, payroll spending and targeted transfers) in Latin America and the Caribbean stand at $4.4 \%$ of GDP in 2015-2016 (Inter-American Development Bank, 2018). Andrade, Gaspar and Bittencourt (2014) use a stochastic frontier model to examine and decompose TFP in Latin America during 1960-2010, concluding that the high share of government current expenditure in the composition of aggregate expenditure in Latin American countries leads to economic inefficiency.
} 
variables, except for the deterministic trend, which is not significant under any acceptable significance level (columns A and B).

Including China could be objected due to the fact that between 1949 and 1978 it was an economy without private companies, its size, and importance within the Asian economies in the sample. Table 2 contains results of cointegration exercises excluding China. The results are broadly similar to those in Table 1 , except for per capita imports, where some easing of the criteria was necessary to reject the null hypothesis: $\mathrm{Ho}=0$, and the case of the deterministic trend, since its coefficient is practically zero in this exercise (column B).

The results in Table 1 and Table 2 imply that the negative effect of public consumption is not offset by the positive effect of public investment; indeed, in columns $\mathrm{A}$ and $\mathrm{B}$ of Table 1 it can be seen that the relative effect of public investment (the ratio of its coefficient to that of public consumption) is, at most, $47.3 \%$ (column B); while in columns $\mathrm{A}$ and $\mathrm{B}$ of Table 2, the relative effect of

Table 2. Estimation results of cointegration models excluding mainland China.

\begin{tabular}{|c|c|c|}
\hline \multicolumn{3}{|l|}{ Dependent variable: Log TFP } \\
\hline Independent variable: & A. Percentage of GDP & B. Per capita \\
\hline Log (public consumption): $L G$ & $\begin{array}{c}-0.72642^{*} \\
{[-4.22412]}\end{array}$ & $\begin{array}{l}-0.814318^{*} \\
{[-5.19468]}\end{array}$ \\
\hline Log (public investment): $L I G$ & $\begin{array}{c}0.203577^{\star * *} \\
{[1.71819]}\end{array}$ & $\begin{array}{l}0.546306^{*} \\
{[4.26199]}\end{array}$ \\
\hline Log (imports): $L M$ & $\begin{array}{l}-0.016385 \\
{[-0.18674]}\end{array}$ & $\begin{array}{c}0.14147^{* * * *} \\
{[1.39349]}\end{array}$ \\
\hline Trend (initial year 1960) & $\begin{array}{c}-0.00017 \\
{[-0.37265]}\end{array}$ & $\begin{array}{c}-0.000915 \\
{[-2.25671]^{\star *}}\end{array}$ \\
\hline Constant & 6.102227 & 6.205452 \\
\hline Determinant resid covariance (dof adj.) & $3.97 \mathrm{E}-09$ & $4.25 \mathrm{E}-09$ \\
\hline Determinant resid covariance & $3.85 \mathrm{E}-09$ & $4.13 \mathrm{E}-09$ \\
\hline Log likelihood & 3189.309 & 3161.951 \\
\hline Akaike information criterion & -7.950462 & -7.881638 \\
\hline Schwarz criterion & -7.779805 & -7.710981 \\
\hline \multicolumn{3}{|l|}{ Adjustment coefficients } \\
\hline alpha 1 & $\begin{array}{c}-0.02964^{\star} \\
{[-6.30310]}\end{array}$ & $\begin{array}{l}-0.019958^{*} \\
{[-5.43227]}\end{array}$ \\
\hline alpha 2 & $\begin{array}{c}-0.00677 \\
{[-1.39669]}\end{array}$ & $\begin{array}{c}-0.020189^{*} \\
{[-5.43967]}\end{array}$ \\
\hline alpha 3 & $\begin{array}{c}0.020548^{\star * *} \\
{[1.85256]}\end{array}$ & $\begin{array}{l}0.012336 \\
{[1.34119]}\end{array}$ \\
\hline alpha 4 & $\begin{array}{c}0.001967 \\
{[0.21192]}\end{array}$ & $\begin{array}{c}-0.00419 \\
{[-0.48932]}\end{array}$ \\
\hline
\end{tabular}

Note: The $t$-values are in square brackets. The significance levels of $1 \%, 5 \%, 10 \%$ and $20 \%$ are indicated by one, two, three and four asterisks, respectively. 
public investment is, at most, $67.1 \%$ (column B) of the impact of public consumption. ${ }^{19}$

Table 1 and Table 2 also show the adjustment coefficients $\left(\alpha_{j}\right)$ and their corresponding $t$ values, in order, of the logarithm of TFP and the logarithms of the explanatory variables (public consumption, public investment and imports), both measured as a percentage of GDP (column A) and in per capita terms (column B), including and excluding China. ${ }^{20}$ This statistical evidence allows testing whether or not the model variables are endogenous, which is equivalent to testing the null hypothesis $\alpha_{j}=0$ against the alternative hypothesis $\alpha_{j} \neq 0$.

The results show that, in all cases, empirical evidence (at conventional statistical significance levels) supports the weak endogeneity of TFP. On the other hand, the adjustment coefficients of the explanatory variables as a percentage of GDP seem to lean more towards the weak exogeneity of public consumption, public investment and imports. In contrast, the adjustment coefficients of the variables in per capita terms show that public spending and imports also seem to react endogenously to the departures of the TFP from its long-term equilibrium when China is included, while public investment seems to be weakly exogenous. Excluding China, per capita public consumption would also react endogenously, while per capita public investment and per capita imports appear to be weakly exogenous.

Another estimation exercise consists of imposing regional dummies defined as follows: Asia (dummy $=0$ ) or Latin America (dummy $=1$ ). These dummies allow capturing the change of slope in the cointegrating relationships for Latin America, differentiating them in the same estimation from those of Asia. Table 3 presents the results of these estimates for the variables as a proportion of GDP and in per capita terms for all economies, while the results of the estimates for the group of economies excluding China are shown in Table 4.

The results obtained for the variables measured as proportions of GDP are quite consistent with the results shown in Table 1 and Table 2: public consumption has a negative effect which, in absolute value, is up to three times the value of the positive effect of public investment, i.e. the positive effects of public investment are not large enough to offset or reverse the negative effects of public consumption on TFP. Imports (which we use as the best variable to approach economic openness) generally have a positive effect that is not statistically significant. The deterministic trend does not seem to be an important determinant in this exercise, although for Latin American countries it has a negative sign. This reflects the decreasing trend of TFP in this region, as previously documented in this article.

In per capita terms, the expected signs for public consumption and investment

${ }^{19}$ This article does not aim to determine the optimal size of public spending. Evidence has been found in the literature of an inverse parabolic relationship between the size of public spending and economic growth. In this regard, the results of Posada and Escobar (2004) and Posada and Gómez (2002) can be considered.

${ }^{20}$ The signs of the coefficients $\alpha_{j}$ indicate the direction or sense of the adjustment. 
Table 3. Estimation results of cointegration models with regional dummies including China.

\begin{tabular}{|c|c|c|c|c|}
\hline \multicolumn{5}{|l|}{ Dependent variable: Log TFP } \\
\hline \multirow[b]{2}{*}{ Independent variables } & \multicolumn{2}{|c|}{ Percentage of GDP } & \multicolumn{2}{|c|}{ Per capita } \\
\hline & All & Latin America & All & $\begin{array}{c}\text { Latin } \\
\text { America }\end{array}$ \\
\hline Log (public consumption): $L G$ & $\begin{array}{l}-2.117895^{\star} \\
{[-7.87052]}\end{array}$ & -0.300467 & $\begin{array}{l}-0.78601^{\star} \\
{[-5.95696]}\end{array}$ & -0.108824 \\
\hline Log (public investment): $L I G$ & $\begin{array}{l}0.698088^{\star} \\
{[3.62107]}\end{array}$ & 0.13285 & $\begin{array}{c}0.251655^{\star \star} \\
{[2.22520]}\end{array}$ & 0.120606 \\
\hline Log (imports): $L M$ & $\begin{array}{l}0.088724 \\
{[0.81718]}\end{array}$ & 0.164454 & $\begin{array}{l}0.291973^{\star} \\
{[5.00668]}\end{array}$ & 0.212975 \\
\hline DUM_REGLGPIB & $\begin{array}{l}1.817428^{*} \\
{[4.34998]}\end{array}$ & & $\begin{array}{l}0.677186^{*} \\
{[3.57364]}\end{array}$ & \\
\hline DUM_REGLIGPIB & $\begin{array}{l}-0.565238^{\star *} \\
{[-2.28820]}\end{array}$ & & $\begin{array}{l}-0.131049 \\
{[-0.96222]}\end{array}$ & \\
\hline DUM_REG*LMPIB & $\begin{array}{c}0.07573 \\
{[0.29319]}\end{array}$ & & $\begin{array}{l}-0.078998 \\
{[-0.58597]}\end{array}$ & \\
\hline Trend (initial year 1960) & $\begin{array}{l}0.002442 \\
{[0.35622]}\end{array}$ & -0.019561 & $\begin{array}{l}0.01046^{\star *} \\
{[2.48781]}\end{array}$ & -0.025087 \\
\hline DUM_REG*TIEMPO & $\begin{array}{c}-0.022003^{* * *} \\
{[-1.87463]}\end{array}$ & & $\begin{array}{l}-0.035547^{*} \\
{[-5.14054]}\end{array}$ & \\
\hline Determinant resid covariance (dof adj.) & $4.25 \mathrm{E}-77$ & & $6.83 \mathrm{E}-76$ & \\
\hline Determinant resid covariance & $3.82 \mathrm{E}-77$ & & $6.14 \mathrm{E}-76$ & \\
\hline Log likelihood & 65475.2 & & 65196.25 & \\
\hline Akaike information criterion & -154.1892 & & -153.5312 & \\
\hline Schwarz criterion & -153.6354 & & -152.9775 & \\
\hline Adjustment Coefficients & & & & \\
\hline alpha 1 & $\begin{array}{c}-0.008084^{\star *} \\
{[-2.27783]}\end{array}$ & & $\begin{array}{l}-0.034519^{*} \\
{[-5.77802]}\end{array}$ & \\
\hline alpha 2 & $\begin{array}{l}-0.016294^{*} \\
{[-6.52661]}\end{array}$ & & $\begin{array}{l}-0.019104^{*} \\
{[-4.03264]}\end{array}$ & \\
\hline alpha 3 & $\begin{array}{l}0.006071 \\
{[1.25733]}\end{array}$ & & $\begin{array}{l}0.011845 \\
{[1.35129]}\end{array}$ & \\
\hline alpha 4 & $\begin{array}{l}0.015041^{*} \\
{[3.44586]}\end{array}$ & & $\begin{array}{l}0.023532^{* *} \\
{[2.58058]}\end{array}$ & \\
\hline
\end{tabular}

Note: $t$ values are in square brackets. The significance levels of $1 \%, 5 \%, 10 \%$ and $20 \%$ are indicated by one, two, three and four asterisks, respectively. 
W. A. Gómez Muñoz et al.

Table 4. Estimation results of cointegration models with regional dummies excluding China.

\begin{tabular}{|c|c|c|c|c|}
\hline \multicolumn{5}{|l|}{ Dependent variable: Log TFP } \\
\hline \multirow{2}{*}{ Independent variables } & \multicolumn{2}{|c|}{ GDP percentage } & \multicolumn{2}{|c|}{ Per capita } \\
\hline & All & Latin Am. & Asia & Latin Am. \\
\hline \multirow[t]{2}{*}{ Log (public spending): $L G$} & $-2.938516^{*}$ & -0.275916 & $-1.235985^{*}$ & -0.109866 \\
\hline & {$[-8.53294]$} & & {$[-7.03479]$} & \\
\hline \multirow[t]{2}{*}{ Log (public investment): $L I G$} & $1.632265^{\star}$ & 0.146014 & $0.484514^{\star}$ & 0.1229 \\
\hline & {$[5.42014]$} & & [3.28599] & \\
\hline \multirow[t]{2}{*}{$\log$ (imports): $L M$} & $-0.217724^{\star * * *}$ & 0.168652 & $0.401786^{*}$ & 0.212018 \\
\hline & {$[-1.33729]$} & & {$[5.38025]$} & \\
\hline \multirow[t]{2}{*}{ DUM_REGLGPIB } & $2.6626^{*}$ & & $1.126119^{*}$ & \\
\hline & {$[4.89859]$} & & [4.59117] & \\
\hline \multirow[t]{2}{*}{ DUM_REG*LIGPIB } & $-1.486251^{*}$ & & $-0.361614^{* *}$ & \\
\hline & {$[-4.16271]$} & & {$[-2.05842]$} & \\
\hline \multirow[t]{2}{*}{ DUM_REG*LMPIB } & 0.386376 & & -0.189768 & \\
\hline & {$[1.21830]$} & & {$[-1.11493]$} & \\
\hline \multirow[t]{2}{*}{ Trend (year one: 1960) } & 0.010887 & -0.020291 & $0.00795^{* * * *}$ & -0.02493 \\
\hline & {$[1.18676]$} & & [1.44271] & \\
\hline \multirow[t]{2}{*}{ DUM_REG*TIEMPO } & $-0.031178^{\star *}$ & & $-0.03288^{*}$ & \\
\hline & {$[-2.24810]$} & & {$[-3.72004]$} & \\
\hline Determinant resid covariance (dof adj.) & $3.20 \mathrm{E}-76$ & & $6.63 \mathrm{E}-76$ & \\
\hline Determinant resid covariance & $2.86 \mathrm{E}-76$ & & $5.92 \mathrm{E}-76$ & \\
\hline Log likelihood & 61757.35 & & 60832.38 & \\
\hline Akaike information criterion & -155.1154 & & -152.7884 & \\
\hline Schwarz criterion & -154.5328 & & -152.2058 & \\
\hline \multicolumn{5}{|l|}{ Adjustment coefficients } \\
\hline \multirow[t]{2}{*}{ alpha 1} & -0.003605 & & $-0.017844^{\star}$ & \\
\hline & {$[-1.33759]$} & & {$[-3.72807]$} & \\
\hline \multirow[t]{2}{*}{ alpha 2} & $-0.012951^{\star}$ & & $-0.014316^{\star}$ & \\
\hline & {$[-6.87216]$} & & {$[-3.71357]$} & \\
\hline \multirow[t]{2}{*}{ alpha 3} & $0.009577^{* *}$ & & 0.011445 & \\
\hline & {$[2.55951]$} & & {$[1.66943]$} & \\
\hline \multirow[t]{2}{*}{ alpha 4} & $0.01129^{*}$ & & $0.030135^{\star}$ & \\
\hline & {$[3.60262]$} & & {$[4.30811]$} & \\
\hline
\end{tabular}

Note: $\mathrm{t}$ values are in square brackets. The significance levels of $1 \%, 5 \%, 10 \%$ and $20 \%$ are indicated by one, two, three and four asterisks, respectively. 
remain: negative for consumption and positive for investment in all economies. However, in the case of Latin America, the positive effect of the latter is slightly greater than the negative effect of consumption. Imports have a positive effect for Asia and Latin America, although for the latter it is not statistically significant. The time trend is negative and significant for Latin America, but this time it is positive and significant for Asia.

The adjustment coefficients in the lower panel of Table 3 and Table 4 show interesting short-term dynamics that go hand in hand with our main hypothesis. The $\alpha_{1}$ coefficients show the short-term adjustment of the TFP variable as it departs from the long-term relationship contained in the cointegration vector and its respectively subsequent endogeneity. In other words, in this exercise not only can the long-term relationship between TFP and the variables considered be identified and estimated, but evidence of the endogeneity of TFP can also be extracted. $^{21}$ A surprising result, in line with our initial hypothesis, is the endogeneity of public consumption (reflected in the $\alpha_{2}$ statistically significant coefficients), which suggests that this is an automatic stabilizer. This means that it seems to work as a short-term buffer, but with negative effects in the long term. For its part, public investment is exogenous (which is reflected in the $\alpha_{3}$ coefficients), and thus statistically significant. Then, this can result from decisions that have a distant relationship with the economic cycle, but rather with decisions that affect the long-term dynamics and structure of economies. Finally, imports appear to be endogenous, thus suggesting that openness, measured in terms of imports, would be more of an outcome than a cause of TFP growth.

\section{Summary and Conclusion}

At the beginning of the 1960s, the set of nine Central-East Asian economies that are now considered as successful economies (China Mainland, Hong Kong, Taiwan, South Korea, India, Indonesia, Malaysia, Singapore, and Thailand) had a lower per capita income than the set of (at that time) the seven main Latin American economies (Argentina, Brazil, Chile, Colombia, Mexico, Peru, and Venezuela). In the second decade of the $21^{\text {st }}$ century, the gap disappeared. Why? Several economists have rightly pointed out that what prima facie explains this development-which was undoubtedly unforeseen by overseers 60 years ago-has been primarily the different evolution of the TFP (i.e. it has been much faster in Central-East Asia than in Latin America) and, secondarily, the intensity with which the two basic production factors-physical and human capitals-have accumulated, which are higher in Central-East Asia and lower in Latin America.

The objective of this study was to try to understand what might explain the greater or lesser TFP growth rate in the economies of both regions. Our scope was not (nor did it attempt to be) deep enough to reach the so-called "root caus-

${ }^{21}$ TFP does not pass the endogeneity test only in the estimation with regional dummies excluding China and as a percentage of GDP. 
es". However, we managed to find statistical evidence, derived from an econometric exercise favorable to one hypothesis: the increase in public consumption expenditure, given the evolution of other factors, is a depressing factor for TFP in the long term. This hypothesis certainly partakes theoretical support and, according to our econometric results, could still be considered plausible.

Other results of the econometric exercise, which are related to hypothetical positive effects of public investment and imports on TFP, were in some cases not as robust or as reliable as they might have been expected. Therefore, in light of the econometric results, we can conclude that if the Latin American economies had slowed down public consumption, by limiting it to what was required to guarantee the rule of law, national sovereignty and universal coverage in basic education and health, their per capita income would probably have risen much higher and the old gaps between them and the East Asian economies would have been maintained or attended more favorably.

\section{Acknowledgements}

Preliminary stages of this study were presented in research seminaries at Universidad EAFIT, Banco de la República (Medellín), Banco de la República (Bogotá), Universidad de Antioquia (Departamento de Economía) and Universidad del Norte. Authors are thankful with participants of seminaries for the comments received.

\section{Conflicts of Interest}

The authors declare no conflicts of interest regarding the publication of this paper.

\section{References}

Akcigit, U., Grigsby, J., Nicholas, T., \& Stantcheva, S. (2018). Taxation and Innovation in the 20th Century. NBER Working Paper No. 2018-71. https://doi.org/10.3386/w24982

Andrade, J., Gaspar, D., \& Bittencourt da Silva, A. (2014). América Latina: Productividad total de los factores y su descomposición. Revista CEPAL, 114, 53-69. https://doi.org/10.18356/0e0eafe2-es

Arslanalp, S., Bornhorst, F., \& Gupta, S. (2011). Inversión y crecimiento. Finanzas \& Desarrollo, 48, 34-37. https://doi.org/10.5089/9781455215638.022

Arslanalp, S., Bornhorst, F., Gupta, S., \& Sze, E. (2010). Public Capital and Growth. IMF, Working Paper No. 10/175. https://doi.org/10.5089/9781455201860.001

Aschauer, D. A. (1989). Is Public Expenditure Productive? Journal of Monetary Economics, 23, 177-200. https://doi.org/10.1016/0304-3932(89)90047-0

Bai, J., \& Ng, S. (2002). Determining the Number of Factors in Approximate Factor Models. Econometrica, 70, 191-221. https://doi.org/10.1111/1468-0262.00273

Bai, J., \& Ng, S. (2004). A Panic Attack on Unit Roots and Cointegration. Econometrica, 72, 1127-1177. https://doi.org/10.1111/j.1468-0262.2004.00528.x

Bai, J., \& Ng, S. (2010). Panel Unit Root Test with Cross-Section Dependence: A Further Investigation. Econometric Theory, 26, 1088-1114. 
https://doi.org/10.1017/S0266466609990478

Barro, R., \& Lee, J. (1994). Sources of Economic Growth. Carnegie-Rochester, Conference Series on Public Policy, 40, 1-46. https://doi.org/10.1016/0167-2231(94)90002-7

Breitung, J., \& Pesaran, M. H. (2005). Unit Roots and Cointegration in Panels. CESifo Working Paper No. 1565.

Bronder, S. (2015). Package "PANICr". https://cran.r-project.org/web/packages/PANICr/index.html

Cai, J., Chen, Y., \& Wang, X. (2018). The Impact of Corporate Taxes on Firm Innovation: Evidence from the Corporate Tax Collection Reform in China. NBER Working Paper No. 25146. https://doi.org/10.3386/w25146

Croissant, Y., \& Millo, G. (2008). Panel Data Econometrics in R: The PLM Package. https://cran.r-project.org/web/packages/plm/vignettes/plm.pdf

De la Fuente, A. (2010). Infrastructures and Productivity: An Updated Survey. UFAE and IAE Working Papers 831.10. Unitat de Fonaments de l'Anàlisi Econòmica (UAB) and Institut d'Anàlisi Econòmica (CSIC).

Easterly, W., \& Levine, R. (2001). It's Not Factor Accumulation: Stylized Facts and Growth Models. The World Bank Economic Review, 15, 177-219. https://doi.org/10.1093/wber/15.2.177

Edwards, S. (1998). Openness, Productivity and Growth: What Do We Really Know? The Economic Journal, 108, 383-398. https://doi.org/10.1111/1468-0297.00293

Feenstra, R., Inklaar, R., \& Timmer, M. (2015). The Next Generation of the Penn World Tables. American Economic Review, 105, 3150-3182. https://doi.org/10.1257/aer.20130954

Fernández-Arias, E. (2014). Productivity and Factor Accumulation in Latin America and the Caribbean: A Database(2014 Update). IDB. https://publications.iadb.org/handle/11319/8402?locale-attribute=es\&

Fernández-Arias, E. (2017). On the Role of Productivity and Factor Accumulation in Economic Development in Latin America and the Caribbean. IDB. Technical Note No. IDB-TN-1329, October. https://doi.org/10.18235/0000919

FMI (2016). Fiscal Affairs Department. Investment and Capital Stock Dataset, 1960-2015.

Gollin, D. (2002). Getting Income Shares Right. Journal of Political Economy, 110, 458-474. https://doi.org/10.1086/338747

Hurlin, C., \& Mignon, V. (2007). Second Generation Panel Unit Root Tests.

Inter-American Development Bank (2018). La (in)eficiencia del gasto público. In A. Izquierdo, C. Pessino, \& G. Vuletin (Eds.), Mejor gasto para mejores vidas. Cómo América Latina y el Caribe puede hacer más con menos. Washintgton DC: Inter-American Development Bank.

Karabarbounis, L., \& Neiman, B. (2014). The Global Decline of the Labor Share. Quarterly Journal of Economics, 129, 61-103. https://doi.org/10.1093/qje/qjt032

Kleiber, C., \& Lupi, C. (2011). Panel Unit Root Testing with $R$. https://r-forge.r-project.org/scm/viewvc.php/* ${ }^{*}$ checkout*/pkg/inst/doc/panelUnitRoot WithR.pdf?root=punitroots

La Ferrara, E., \& Marcellino, M. (2000). TFP, Costs, and Public Infrastructure: An Equivocal Relationship. Bocconi University and IGIER, October. https://doi.org/10.2139/ssrn.262511

Lederman, D. (1996). The Sources of Economic Growth: A Survey from a Latin America Perspective. Washington DC: The World Bank, Office of the Chief Economist of Latin 
America and the Caribbean Region.

Loayza, N., Fajnzylber, P., \& Calderón, C. (2005). Economic Growth in Latin America and the Caribbean: Stylized Facts, Explanations, and Forecasts. Washington DC: The World Bank. https://doi.org/10.1596/0-8213-6091-4

Lupi, C. (2011). Panel-CADF Testing with R: Panel Unit Root Tests Made Easy. Economics \& Statistics Discussion Paper No. 063/11. Università degli Studi del Molise, Dipartimento di Scienze economiche, Gestionali e Sociali (SEGeS).

Munnell, A. (1992). Infraestructure Investment and Economic Growth. Journal of Economics Perspectives, 6, 189-198. https://doi.org/10.1257/jep.6.4.189

Pesaran, M. H. (2007). A Simple Panel Unit Root Test in the Presence of Cross-Section Dependence. Journal of Applied Econometrics, 22, 265-312. https://doi.org/10.1002/jae.951

Posada, C. E. (2015). El costo de oportunidad del cambio técnico, el crecimiento económico y el caso colombiano 1925-2012. Revista Ensayos sobre Política Económica, 33, 149-167. https://doi.org/10.1016/j.espe.2015.04.002

Posada, C. E., \& Escobar, J. F. (2004). Crecimiento económico y gasto público: Experiencias internacionales y el caso colombiano 1982-99. Monetaria, 27, 131-167. https://doi.org/10.32468/be.258

Posada, C. E., \& Gómez, W. (2002). Crecimiento económico y gasto público: Un modelo para el caso colombiano. Revista ESPE-Ensayos sobre Política Económica, Banco de la Republica de Colombia, 20, 5-86. https://doi.org/10.32468/Espe.41-4201

Pritchett, L. (1996). Measuring Outward Orientation in LDCs: Can It Be Done? Journal of Development Economics, 49, 307-335. https://doi.org/10.1016/0304-3878(95)00064-X

Ros, J. (2014). Productividad y crecimiento en América Latina: Por qué la productividad crece más en unas economías que en otras? México: CEPAL.

Shibamoto, M., Tsutsui, Y., \& Yamane, C. (2016). Understanding Regional Growth Dynamics in Japan: Panel Cointegration Approach Utilizing the PANIC Method. Discussion Paper Series, RIEB-Kobe University, DP243. https://doi.org/10.1016/j.jjie.2016.03.004

Shu, P., \& Steinwender, C. (2018). The Impact of Trade Liberalization on Firm Productivity and Innovation. NBER, Working Paper No. 24715, June.

Straub, S. (2008). Infrastructure and Development: A Critical Appraisal of the Macro Level Literature. Policy Research Working Paper, WPS4590, Washington DC: The World Bank. https://doi.org/10.1596/1813-9450-4590

The World Bank (2007). Fiscal Policy for Growth and Development: Further Analysis and Lessons from Country Case Studies. Washington DC: The World Bank.

The World Bank Commission on Growth and Development (2008). The Growth Report: Strategies for Sustained Growth and Inclusive Development. Washington DC: The World Bank. 


\section{Annex 1. Cointegration and Estimation Tests Results of} "Cointegration Vector and Error Correction"

Table A.1.1. Cointegration tests for imports/GDP and exports/GDP (LMPIB and LXPIB)

\begin{tabular}{|c|c|c|c|c|c|}
\hline \multicolumn{6}{|c|}{ Specification: linear deterministic trend } \\
\hline Region & $\begin{array}{l}\text { Hypothesized } \\
\text { No. of CE(s) }\end{array}$ & $\begin{array}{l}\text { Fisher Stat.* } \\
\text { (from trace test) }\end{array}$ & Prob. & $\begin{array}{c}\text { Fisher Stat.* } \\
\text { (from max-eigen test) }\end{array}$ & Prob. \\
\hline \multirow[t]{2}{*}{ Asia } & None & 34.3 & 0.0116 & 30.51 & 0.0328 \\
\hline & At most 1 & 16.34 & 0.5691 & 16.34 & 0.5691 \\
\hline \multirow[t]{2}{*}{ Latam } & None & 20.19 & 0.1244 & 18.28 & 0.1945 \\
\hline & At most 1 & 10.91 & 0.6927 & 10.91 & 0.6927 \\
\hline \multirow[t]{2}{*}{ All } & None & 48.59 & 0.0303 & 44.52 & 0.0697 \\
\hline & At most 1 & 25.35 & 0.7914 & 25.35 & 0.7914 \\
\hline \multicolumn{6}{|c|}{ Specification without linear deterministic trend } \\
\hline Region & $\begin{array}{l}\text { Hypothesized } \\
\text { No. of } \mathrm{CE}(\mathrm{s})\end{array}$ & $\begin{array}{l}\text { Fisher Stat.* } \\
\text { (from trace test) }\end{array}$ & Prob. & $\begin{array}{c}\text { Fisher Stat.* } \\
\text { (from max-eigen test) }\end{array}$ & Prob. \\
\hline \multirow[t]{2}{*}{ Asia } & None & 50.67 & 0.0001 & 45.66 & 0.0003 \\
\hline & At most 1 & 27.45 & 0.0709 & 27.45 & 0.0709 \\
\hline \multirow[t]{2}{*}{ Latam } & None & 26.27 & 0.0239 & 24.78 & 0.0368 \\
\hline & At most 1 & 17.25 & 0.2431 & 17.25 & 0.2431 \\
\hline \multirow[t]{2}{*}{ All } & None & 65.73 & 0.0004 & 63.33 & 0.0008 \\
\hline & At most 1 & 38.13 & 0.2105 & 38.13 & 0.2105 \\
\hline
\end{tabular}

Table A.1.2. Cointegration tests results for variables (in logarithms): TFP, public consumption/GDP, public investment/GDP and imports/GDP, LPTF, LGPIB, LIGPIB and LMPIB (including China).

\begin{tabular}{|c|c|c|c|c|c|}
\hline \multicolumn{6}{|c|}{ Specification: linear deterministic trend } \\
\hline Variables & $\begin{array}{l}\text { Hypothesized } \\
\text { No. of CE(s) }\end{array}$ & $\begin{array}{l}\text { Fisher Stat.* } \\
\text { (from trace test) }\end{array}$ & $\begin{array}{c}0 \\
\text { Prob. }\end{array}$ & $\begin{array}{c}\text { Fisher Stat.* } \\
\text { (from max-eigen test) }\end{array}$ & $\begin{array}{c}0 \\
\text { Prob. }\end{array}$ \\
\hline \multirow[t]{4}{*}{ GDP \% } & None & 110.2 & 0 & 76.63 & 0 \\
\hline & At most 1 & 54.4 & 0.008 & 38.07 & 0.2126 \\
\hline & At most 2 & 35.36 & 0.3125 & 24.75 & 0.8159 \\
\hline & At most 3 & 27.76 & 0.6813 & 27.76 & 0.6813 \\
\hline \multirow[t]{4}{*}{ per capita } & None & 132.6 & 0 & 115.9 & 0 \\
\hline & At most 1 & 49.47 & 0.0251 & 41.78 & 0.1156 \\
\hline & At most 2 & 26.2 & 0.7545 & 21.95 & 0.9087 \\
\hline & At most 3 & 21.88 & 0.9105 & 21.88 & 0.9105 \\
\hline
\end{tabular}

\section{Annex 2. Endogeneity vs Exogeneity}

Equation models (A1) and (A2) correspond to VEC models estimated for per capita variables or as GDP proportions in this exercise. 


$$
\begin{aligned}
& {\left[\begin{array}{c}
\Delta \log \left(P T F_{i t}\right) \\
\Delta \log \left(\text { GPIB }_{i t}\right) \\
\Delta \log \left(\text { IGPIB }_{i t}\right) \\
\Delta \log \left(M P I B_{i t}\right)
\end{array}\right]} \\
& =\left[\begin{array}{c}
c_{1} \\
c_{2} \\
c_{3} \\
c_{4}
\end{array}\right]+\left[\begin{array}{c}
\alpha_{1} \\
\alpha_{2} \\
\alpha_{3} \\
\alpha_{4}
\end{array}\right]\left[\begin{array}{llllll}
1 & \beta_{0} & \beta_{1} & \beta_{2} & \beta_{3} & \beta_{4}
\end{array}\right]\left[\begin{array}{c}
\log \left(P T F_{i t-1}\right) \\
1 \\
\log \left(G P I B_{i t-1}\right) \\
\log \left(I G P I B_{i t-1}\right) \\
\log \left(M P I B_{i t-1}\right) \\
t-1
\end{array}\right] \\
& +\left[\begin{array}{llll}
\pi_{11} & \pi_{12} & \pi_{13} & \pi_{14} \\
\pi_{21} & \pi_{22} & \pi_{23} & \pi_{24} \\
\pi_{31} & \pi_{32} & \pi_{33} & \pi_{34} \\
\pi_{41} & \pi_{42} & \pi_{43} & \pi_{44}
\end{array}\right]\left[\begin{array}{c}
\Delta \log \left(P T F_{i t-1}\right) \\
\Delta \log \left(G P I B_{i t-1}\right) \\
\left.\Delta \log (I) I B_{i t-1}\right) \\
\Delta \log \left(M P I B_{i t-1}\right)
\end{array}\right]+\left[\begin{array}{c}
\varepsilon_{1 i t} \\
\varepsilon_{2 i t} \\
\varepsilon_{3 i t} \\
\varepsilon_{4 i t}
\end{array}\right]
\end{aligned}
$$

And in per capita terms:

$$
\begin{aligned}
& {\left[\begin{array}{c}
\Delta \log \left(P T F_{i t}\right) \\
\Delta \log \left(G P I B_{i t}\right) \\
\Delta \log \left(I G P I B_{i t}\right) \\
\Delta \log \left(M P I B_{i t}\right)
\end{array}\right]} \\
& =\left[\begin{array}{l}
c_{1} \\
c_{2} \\
c_{3} \\
c_{4}
\end{array}\right]+\left[\begin{array}{c}
\alpha_{1} \\
\alpha_{2} \\
\alpha_{3} \\
\alpha_{4}
\end{array}\right]\left[\begin{array}{llllll}
1 & \beta_{0} & \beta_{1} & \beta_{2} & \beta_{3} & \beta_{4}
\end{array}\right]\left[\begin{array}{c}
\log \left(P T F_{i t-1}\right) \\
1 \\
\log \left(G_{i t-1}\right) \\
\log \left(I G_{i t-1}\right) \\
\log \left(M_{i t-1}\right) \\
t-1
\end{array}\right] \\
& +\left[\begin{array}{llll}
\pi_{11} & \pi_{12} & \pi_{13} & \pi_{14} \\
\pi_{21} & \pi_{22} & \pi_{23} & \pi_{24} \\
\pi_{31} & \pi_{32} & \pi_{33} & \pi_{34} \\
\pi_{41} & \pi_{42} & \pi_{43} & \pi_{44}
\end{array}\right]\left[\begin{array}{c}
\Delta \log \left(P T F_{i t-1}\right) \\
\Delta \log \left(G_{i t-1}\right) \\
\Delta \log \left(I G_{i t-1}\right) \\
\Delta \log \left(M_{i t-1}\right)
\end{array}\right]+\left[\begin{array}{c}
\varepsilon_{1 i t} \\
\varepsilon_{2 i t} \\
\varepsilon_{3 i t} \\
\varepsilon_{4 i t}
\end{array}\right]
\end{aligned}
$$

In a more compact and general way, these models can be written as:

$$
\begin{aligned}
& \Delta Y_{i t}=\Gamma+\Pi_{0} Y_{i t-1}+\sum_{k=1}^{p} \Pi_{k} \Delta Y_{i t-k}+\varepsilon_{i t} \\
& \Delta Y_{i t}=\Gamma+\alpha \beta Y_{i t-1}+\sum_{k=1}^{p} \Pi_{k} \Delta Y_{i t-k}+\varepsilon_{i t}
\end{aligned}
$$

Being $\Pi_{0}=\alpha \beta$

The row vector $\beta$ shows the cointegration vector or long run relationship, while column vector $\alpha$ shows the adjustment speeds (and signs or directions) of growth rates of the dependent variables when their movement (in period $t-$ 1) moved them away from their stationary state or long run situation. For their part, matrices $\Pi_{k}$ include the effects of $\Delta Y_{i t-k}, k=1,2,3, \cdots, p$ on the evolution of the existing growth rates of variables. Intuitively, if a variable $j$ reacts (its behavior is induced) by the distances or deviations regarding the long run, it is 
said that this variable responds endogenously to the behavior of the others, which occurs when its adjustment coefficient $\alpha_{j}$ is different from zero. But when the value of $\alpha_{j}$ is zero, the growth rate is explained only by the dynamics of the lags of the other variables and of itself. Then, there is no long run dynamics, therefore the model contained in expressions (A1) to (A4) takes the form of a VAR in first differences. In this case, it is claimed that this variable is weakly exogenous or that there is evidence of weak endogeneity. The notion of "weak" arises because this form of VAR in first differences shows the causal relations that can exist between differentiated variables.

\section{Annex 3. Aggregate Productivity and Public Spending}

The standard estimate of aggregate productivity (TFP) considers annual production $Y$ (measured by GDP) and estimates of available accumulated factors of production. These are the physical capital and the human capital. TFP measures the efficiency by which accumulated production factors are used to generate the product. The contributions of factors of production and TFP to the product are estimated using a relevant production function. The Cobb-Douglas production function we use has the following form:

$$
Y=K^{\alpha}(A h L)^{1-\alpha}
$$

Being $K$ the stock of physical capital, $h L$ the number of workers $(L)$ multiplied by the index of human capital per worker $(h) ; A$ is total factor productivity and $\alpha$ is product's elasticity with respect to physical capital.

The parameter of the production function $(\alpha)$ is set at 0.434 (Fernández-Arias, 2014). ${ }^{22}$ Although there is some debate about the validity of this assumption of uniformity, Gollin (2002) shows that once informal work and family businesses are taken into account, there is no systematic difference between countries that could be associated with their levels of development (GDP per capita), nor with any time trend. Therefore, its uniformity between countries and over time seems to be a reasonable assumption. This assumption also implies that any technological change that has occurred since 1960 is reflected in measure A of multifactor productivity (Fernández-Arias, 2017).

Equation (1) implies:

$$
A=\left[\frac{Y}{K^{\alpha}(h L)^{1-\alpha}}\right]^{\frac{1}{1-\alpha}}
$$

TFP (variable $A$ in equation 2) is a residual that can reflect advances in technology (the "instructions" for producing goods and services) and those arising from changes in micro efficiency or the general economic environment in which production takes place, efficiency in the functioning of markets, ${ }^{23}$ externalities,

\footnotetext{
${ }^{22}$ This value corresponds to the average of the cross-country elasticities estimated in 1960 (the base year) in Penn World Tables 8.0 (Fernandez-Arias, 2014).

${ }^{23}$ For instance, policies can distort the efficiency with which factors are allocated across sectors and across companies within sectors, thus reducing efficiency at the aggregate level.
} 
increasing returns and economies of scale, changes in the composition of productive sectors, and the adoption of lower-cost production methods. Consequently, TFP is a comprehensive (broad) measure of efficiency whereby the economy can transform its accumulated factors of production into production (Fernández-Arias, 2017).

\section{Annex 4. Sources of Data to Build TFP and for the Analysis of Its Determinants}

Table A.4. Sources and databases.

\begin{tabular}{|c|c|c|}
\hline Variable & Description & Source \\
\hline$Y$ & Real GDP at constant 2011 national prices (in millions 2011 US\$) & PWT 9.0 \\
\hline$K$ & $\begin{array}{l}\text { Capital stock at constant } 2011 \text { national prices (in millions } 2011 \\
\text { US\$) }\end{array}$ & PWT 9.0 \\
\hline$L$ & Number of persons engaged (in millions) & PWT 9.0 \\
\hline$h$ & $\begin{array}{l}\text { Human capital index per person, based on years of schooling and } \\
\text { returns to education. }\end{array}$ & PWT 9.0 \\
\hline Population & Population Level (000 at midyear) & $\begin{array}{c}\text { Maddison } \\
\text { Database }\end{array}$ \\
\hline$C_{g} / Y$ & $\begin{array}{l}\text { Government consumption/GDP, both at constant national } 2011 \\
\text { prices }\end{array}$ & PWT 9.0 \\
\hline$M / Y$ & Imports/GDP, both at constant national 2011 prices & PWT 9.0 \\
\hline$I_{g} / Y$ & $\begin{array}{l}\text { General government investment (gross fixed capital formation)/ } \\
\text { GDP, both in billions of constant } 2011 \text { international dollars }\end{array}$ & $\begin{array}{l}\text { FMI, Fiscal } \\
\text { Affairs } \\
\text { Department }\end{array}$ \\
\hline
\end{tabular}

In the case of Argentina, data from Real GDP at constant national prices (in millions 2011 US\$) were constructed based on growth rates reported in The Conference Board-Total Economy Database, based on Real GDP in 2011 obtained from PWT 9.0. The physical capital stock is calculated from the capital-output ratio of the PWT 9.0 data. Similarly, the employment data were taken from The Conference Board-Total Economy Database (persons employed). The share of government consumption in GDP corresponds to its nominal values in national currency according to PWT 9.0.

\section{Public spending}

The share of public spending in the GDP of the economies described below does not correspond to that of the other economies in the sample, due to the problems observed in the series obtained from PWT referenced in the table above.

In Brazil, the share of government consumption in GDP is calculated as the average of the shares at constant prices (corrected by own calculations) and at current prices, both in national currency, reported by ECLAC.

In Mexico, the share of government consumption in GDP corresponds to data 
reported by PWT 9.0 as csh_g. Share of government consumption at current PPPs.

In Venezuela, the share of government consumption in GDP is calculated by correcting the inflation rates of the implicit deflators of government consumption expenditures in national currency for some years that PWT shows, assuming that they are equal to the inflation rates of the GDP deflators. This correction makes it possible to obtain a series of such expenditures in real terms in national currency and thus the share of public consumption in GDP at constant prices in national currency during the period 1950-1997. The share of public consumption in GDP at constant prices for the period 1997-2014 was obtained from ECLAC and then linked backwards (1950-1996) to the growth rates of the corrected real share.

Finally, the shares of public consumption in the GDP of all economies are multiplied by Real GDP at constant 2011 national prices (in millions 2011 US\$) from PWT 9.0 to obtain the public consumption in constant 2011 national prices (in millions 2011US\$), thereby obtaining the corresponding figures in per capita terms.

\section{Annex 5. Estimates Using TFP Calculated with Product to Capital Elasticities (" $\alpha$ ") Which Differ by Country and Over Time}

The stability of factor share in income has been a fundamental basis for macroeconomic models since Kaldor's famous stylized facts (1957). As is known, this restriction has important macroeconomic implications. However, in the last two decades some works have found an important variability in labor share in the medium term and a downward trend in the last three or four decades. For instance, Karabarbounis and Neiman (2014) find a significant decline in global labor share since the early 1980s. This decline is observed in most countries and industries. Likewise, thorough estimates of labor share included in the new version of Penn World Tables show a similar trend (Feenstra, Inklaar, \& Timmer, 2015).

This annex presents the results of the cointegration exercise using the TFP index for the sample countries reported by PWT 9.0 but calculated using different shares between countries and over time.

Table A.5.1 (including China) shows that none of the variables as a percentage of GDP was significant as a determinant of multifactor productivity. In contrast, in per capita terms, the signs of the estimated coefficients for public spending (consumption), imports, and public investment are as expected: Negative for the former and positive for the latter two. The coefficients of public spending and imports are significant at conventional levels of significance, while public investment is significant at levels of significance of $10 \%$. For its part, the deterministic trend was not significant. 
W. A. Gómez Muñoz et al.

Table A.5.1. Results of cointegration models including China.

\begin{tabular}{|c|c|c|c|}
\hline & Variables & $\begin{array}{c}\text { A } \\
\text { Percentages of GDP }\end{array}$ & $\begin{array}{c}\text { B } \\
\text { Per capita }\end{array}$ \\
\hline \multirow{23}{*}{ 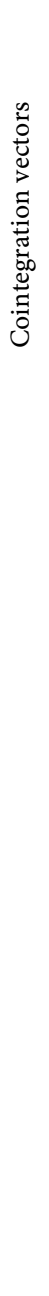 } & LPTFNUEVA $(-1)$ & 1 & 1 \\
\hline & LG $(-1)$ & -0.009862 & $0.298708^{*}$ \\
\hline & & {$[-0.09862]$} & {$[3.57830]$} \\
\hline & LIG $(-1)$ & 0.021308 & -0.113861 \\
\hline & & {$[0.33866]$} & {$[-1.82979]^{* * *}$} \\
\hline & $\operatorname{LM}(-1)$ & -0.017952 & -0.101159 \\
\hline & & {$[-0.35281]$} & {$[-2.13430]^{* *}$} \\
\hline & @TREND (60) & -0.000172 & 0.000155 \\
\hline & & {$[-0.72149]$} & {$[0.80693]$} \\
\hline & $\mathrm{C}$ & -4.38246 & -5.224349 \\
\hline & Determinant resid covariance (dof adj.) & $1.30 \mathrm{E}-09$ & $1.25 \mathrm{E}-09$ \\
\hline & Determinant resid covariance & $1.26 \mathrm{E}-09$ & $1.19 \mathrm{E}-09$ \\
\hline & Log likelihood & $3.87 \mathrm{E}+03$ & $3.83 \mathrm{E}+03$ \\
\hline & Akaike information criterion & $-9.07 \mathrm{E}+00$ & $-9.09 \mathrm{E}+00$ \\
\hline & Schwarz criterion & $-8.91 \mathrm{E}+00$ & $-8.83 \mathrm{E}+00$ \\
\hline & alpha 1 & -0.031442 & -0.028595 \\
\hline & & {$[-7.25168]$} & {$[-6.77584]$} \\
\hline & alpha 2 & 0.02613 & -0.037336 \\
\hline & & [3.33755] & {$[-4.94184]$} \\
\hline & alpha 3 & 0.021073 & -0.00709 \\
\hline & & [1.18730] & {$[-0.38253]$} \\
\hline & alpha 4 & -0.024255 & -0.043729 \\
\hline & & {$[-1.56836]$} & {$[-2.50714]$} \\
\hline
\end{tabular}

Note: $t$ values are in square brackets. The significance levels of $1 \%, 5 \%$ and $10 \%$ are indicated by one, two and three asterisks, respectively.

When the exercise was repeated excluding China (Table A.5.2), the effect of public spending on consumption on TFP was significant, whether the variable is measured as a proportion of GDP or in per capita terms.

Table A.5.2. Results of cointegration models excluding China.

\begin{tabular}{|c|c|c|c|}
\hline & Variables & $\begin{array}{c}\text { A } \\
\text { Percentages of GDP }\end{array}$ & $\begin{array}{c}\text { B } \\
\text { Per capita }\end{array}$ \\
\hline \multirow{5}{*}{ 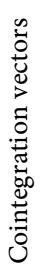 } & LPTFNUEVA $(-1)$ & 1 & 1 \\
\hline & LG $(-1)$ & $0.214224^{\star \star}$ & $0.262913^{\star}$ \\
\hline & & {$[2.37516]$} & {$[3.27817]$} \\
\hline & LIG $(-1)$ & -0.019648 & -0.113747 \\
\hline & & {$[-0.31556]$} & {$[-1.91314]^{* * *}$} \\
\hline
\end{tabular}




\section{Continued}

\begin{tabular}{|c|c|c|}
\hline \multirow[t]{2}{*}{$\operatorname{LM}(-1)$} & 0.010318 & $-0.094089^{* *}$ \\
\hline & {$[0.22370]$} & {$[-2.08902]$} \\
\hline \multirow[t]{2}{*}{ @TREND (60) } & -0.000113 & 0.000261 \\
\hline & {$[-0.47249]$} & [1.31359] \\
\hline $\mathrm{C}$ & -5.014693 & -5.078706 \\
\hline Determinant resid covariance ( dof adj.) & $1.25 \mathrm{E}-09$ & $1.24 \mathrm{E}-09$ \\
\hline Determinant resid covariance & $1.21 \mathrm{E}-09$ & $1.18 \mathrm{E}-09$ \\
\hline Log likelihood & $3.65 \mathrm{E}+03$ & $3.59 \mathrm{E}+03$ \\
\hline Akaike information criterion & $-9.11 \mathrm{E}+00$ & $-9.09 \mathrm{E}+00$ \\
\hline Schwarz criterion & $-8.93 \mathrm{E}+00$ & $-8.82 \mathrm{E}+00$ \\
\hline \multirow[t]{2}{*}{ alpha 1} & -0.036674 & -0.029783 \\
\hline & {$[-7.07928]$} & {$[-6.42945]$} \\
\hline \multirow[t]{2}{*}{ alpha 2} & 0.01037 & -0.037166 \\
\hline & [1.07751] & {$[-4.33697]$} \\
\hline \multirow[t]{2}{*}{ alpha 3} & 0.033386 & -0.007474 \\
\hline & [1.51627] & {$[-0.35567]$} \\
\hline \multirow[t]{2}{*}{ alpha 4} & -0.020353 & -0.048309 \\
\hline & {$[-1.10413]$} & {$[-2.45459]$} \\
\hline
\end{tabular}

Note: $\mathrm{t}$ values are in square brackets. The significance levels of $1 \%, 5 \%$ and $10 \%$ are indicated by one, two and three asterisks, respectively.

\section{Annex 6. Unit Root Tests (Individual Deterministic Trends and Constants)}

Table A.6.1. Unit root tests, TFP and per capita variables

\begin{tabular}{|c|c|c|c|c|c|}
\hline Variable & Test & Statistic & Prob $^{* *}$ & $\begin{array}{l}\text { Cross- } \\
\text { sections }\end{array}$ & Obs \\
\hline \multirow[t]{7}{*}{ LPTF } & & \multicolumn{4}{|c|}{ Ho: Unit root (common unit root) } \\
\hline & Levin, Lin \& Chu $t^{*}$ & -2.34285 & 0.0096 & 16 & 859 \\
\hline & \multirow[t]{2}{*}{ Breitung t-stat } & 0.1383 & 0.555 & 16 & 843 \\
\hline & & \multicolumn{4}{|c|}{ Ho: Unit root (individual unit root) } \\
\hline & Im, Pesaran and Shin W-stat & -0.95658 & 0.1694 & 16 & 859 \\
\hline & ADF-Fisher Chi-square & 34.631 & 0.3434 & 16 & 859 \\
\hline & PP-Fisher Chi-square & 35.5284 & 0.3055 & 16 & 864 \\
\hline \multirow[t]{4}{*}{ LG } & & \multicolumn{4}{|c|}{ Ho: Unit root (common unit root) } \\
\hline & Levin, Lin \& Chu $\mathrm{t}^{*}$ & 1.35975 & 0.913 & 16 & 854 \\
\hline & Breitung t-stat & 1.33092 & 0.9084 & 16 & 838 \\
\hline & & \multicolumn{4}{|c|}{ Ho: Unit root (individual unit root) } \\
\hline
\end{tabular}


W. A. Gómez Muñoz et al.

\section{Continued}

\begin{tabular}{|c|c|c|c|c|c|}
\hline & Im, Pesaran and Shin W-stat & 0.38666 & 0.6505 & 16 & 854 \\
\hline & ADF-Fisher Chi-square & 47.3558 & 0.0394 & 16 & 854 \\
\hline & PP-Fisher Chi-square & 64.6822 & 0.0005 & 16 & 864 \\
\hline \multirow[t]{7}{*}{ LIG } & & \multicolumn{4}{|c|}{ Ho: Unit root (common unit root) } \\
\hline & Levin, Lin \& Chu $\mathrm{t}^{\star}$ & 0.32254 & 0.6265 & 16 & 852 \\
\hline & \multirow[t]{2}{*}{ Breitung t-stat } & 0.55855 & 0.7118 & 16 & 836 \\
\hline & & \multicolumn{4}{|c|}{ Ho: Unit root (individual unit root) } \\
\hline & Im, Pesaran and Shin W-stat & 0.11649 & 0.5464 & 16 & 852 \\
\hline & ADF-Fisher Chi-square & 34.0647 & 0.3685 & 16 & 852 \\
\hline & PP-Fisher Chi-square & 18.1863 & 0.9761 & 16 & 864 \\
\hline \multirow[t]{7}{*}{ LM } & & \multicolumn{4}{|c|}{ Ho: Unit root (common unit root) } \\
\hline & Levin, Lin \& Chu $t^{*}$ & 0.01066 & 0.5043 & 16 & 859 \\
\hline & Breitung t-stat & 0.88557 & 0.8121 & 16 & 843 \\
\hline & & \multicolumn{4}{|c|}{ Ho: Unit root (individual unit root) } \\
\hline & Im, Pesaran and Shin W-stat & 0.43151 & 0.6669 & 16 & 859 \\
\hline & ADF-Fisher Chi-square & 29.9636 & 0.57 & 16 & 859 \\
\hline & PP-Fisher Chi-square & 39.1414 & 0.1799 & 16 & 864 \\
\hline
\end{tabular}

Table A.6.2. Unit root tests, variables as GDP proportion.

\begin{tabular}{|c|c|c|c|c|c|}
\hline Variable & Test & Statistic & Prob** & $\begin{array}{l}\text { Cross- } \\
\text { sections }\end{array}$ & Obs \\
\hline \multirow[t]{7}{*}{ LGPIB } & \multicolumn{5}{|c|}{ Ho: Unit root (common unit root) } \\
\hline & Levin, Lin \& Chu $\mathrm{t}^{*}$ & -1.0576 & 0.1451 & 16 & 838 \\
\hline & Breitung t-stat & -1.3449 & 0.0893 & 16 & 822 \\
\hline & \multicolumn{5}{|c|}{ Ho: Unit root (individual unit root) } \\
\hline & Im, Pesaran and Shin W-stat & -1.31808 & 0.0937 & 16 & 838 \\
\hline & ADF-Fisher Chi-square & 43.5176 & 0.0842 & 16 & 838 \\
\hline & $\mathrm{PP}$-Fisher Chi-square & 38.8259 & 0.1891 & 16 & 864 \\
\hline
\end{tabular}

LIGPIB

Ho: Unit root (common unit root)

$\begin{array}{ccccc}\text { Levin, Lin \& Chu t* } & -1.00081 & 0.1585 & 16 & 858 \\ \text { Breitung t-stat } & -1.16582 & 0.1218 & 16 & 842\end{array}$

Ho: Unit root (individual unit root)

$\begin{array}{ccccc}\text { Im, Pesaran and Shin W-stat } & -1.2211 & 0.111 & 16 & 858 \\ \text { ADF-Fisher Chi-square } & 43.0943 & 0.0911 & 16 & 858 \\ \text { PP-Fisher Chi-square } & 28.712 & 0.6337 & 16 & 864\end{array}$

LMPIB

Ho: Unit root (common unit root)

$\begin{array}{ccccc}\text { Levin, Lin \& Chu t* } & -2.40998 & 0.008 & 16 & 850 \\ \text { Breitung t-stat } & -0.03801 & 0.4848 & 16 & 834\end{array}$




\section{Continued}

Ho: Unit root (individual unit root)

$\begin{array}{ccccc}\text { Im, Pesaran and Shin W-stat } & -1.79969 & 0.036 & 16 & 850 \\ \text { ADF-Fisher Chi-square } & 43.0057 & 0.0926 & 16 & 850 \\ \text { PP-Fisher Chi-square } & 36.9657 & 0.2503 & 16 & 864\end{array}$

Table A.6.3. Stationary tests.

\begin{tabular}{cccc}
\hline Variable & Method & Statistic & Prob $^{* *}$ \\
\hline LPTF & Hadri Z-stat & 9.29993 & 0 \\
& Heteroscedastic Consistent Z-stat & 8.93155 & 0 \\
LG & Hadri Z-stat & 9.66802 & 0 \\
& Heteroscedastic Consistent Z-stat & 8.10874 & 0 \\
LIG & Hadri Z-stat & 9.1742 & 0 \\
& Heteroscedastic Consistent Z-stat & 8.10498 & 0 \\
LM & Hadri Z-stat & 11.4816 & 0 \\
& Heteroscedastic Consistent Z-stat & 9.77246 & 0 \\
LGPIB & Hadri Z-stat & 7.87163 & 0 \\
& Heteroscedastic Consistent Z-stat & 7.50091 & 0 \\
LIGPIB & Hadri Z-stat & 7.87163 & 0 \\
& Heteroscedastic Consistent Z-stat & 7.50091 & 0 \\
& Hadri Z-stat & 11.5021 & 0 \\
LMPIB & Heteroscedastic Consistent Z-stat & 10.4336 & 0 \\
& & & \\
\hline
\end{tabular}

Note: these tests are available in Eviews and R.

Table A.6.4. PANIC tests 2010.

\begin{tabular}{|c|c|c|c|c|}
\hline \multirow{2}{*}{ Variable } & \multicolumn{4}{|c|}{ Model with constant and deterministc trend } \\
\hline & Pooled & Pool.value & Model.C & Model.C \\
\hline \multirow[t]{4}{*}{ LPTF } & $\mathrm{Pa}$ & 0.2906267 & ta & -1.362829 \\
\hline & $\mathrm{Pb}$ & 0.3040682 & $\mathrm{tb}$ & -1.403293 \\
\hline & & PMSB & rhol & Pool.ADF \\
\hline & & 0.3562268 & 0.9856549 & -0.3700467 \\
\hline \multirow[t]{5}{*}{ LGPIB } & Pooled & Pool.value & $\mathrm{C}$ & Model.C \\
\hline & $\mathrm{Pa}$ & 0.2534956 & ta & -1.352104 \\
\hline & $\mathrm{Pb}$ & 0.2632605 & tb & -1.489702 \\
\hline & & PMSB & rhol & Pool.ADF \\
\hline & & 0.3171416 & 0.9868038 & -0.1941862 \\
\hline \multirow[t]{2}{*}{ LIGPIB } & pool_test & P mp_test & 0 & Model.C \\
\hline & $\mathrm{Pa}$ & -1.364742 & ta & 0.6171061 \\
\hline
\end{tabular}


W. A. Gómez Muñoz et al.

\section{Continued}

\begin{tabular}{|c|c|c|c|c|}
\hline & $\mathrm{Pb}$ & -1.201199 & tb & 0.5377475 \\
\hline & & PMSB & rhol & Pool.ADF \\
\hline & & -0.9334927 & 1.005957 & -0.9878564 \\
\hline \multirow[t]{5}{*}{ LMPIB } & Pooled & Pool.value & C & Model.C \\
\hline & $\mathrm{Pa}$ & 0.2534956 & ta & -1.352104 \\
\hline & $\mathrm{Pb}$ & 0.2632605 & tb & -1.489702 \\
\hline & & PMSB & rhol & Pool.ADF \\
\hline & & 0.3171416 & 0.9868038 & -0.1941862 \\
\hline \multirow[t]{5}{*}{ LG } & pool_test & $\mathrm{P}$ & mp_test & Model.C \\
\hline & $\mathrm{Pa}$ & 1.265976 & ta & 0.1746728 \\
\hline & $\mathrm{Pb}$ & 1.566456 & tb & 0.2032701 \\
\hline & & PMSB & rhol & Pool.ADF \\
\hline & & 1.944328 & 1.002024 & 0.08065619 \\
\hline \multirow[t]{5}{*}{ LIG } & pool_test & $\mathrm{P}$ & mp_test & Model.C \\
\hline & $\mathrm{Pa}$ & -0.8847976 & ta & 0.9690096 \\
\hline & $\mathrm{Pb}$ & -0.8095976 & tb & 0.9642431 \\
\hline & & PMSB & rhol & Pool.ADF \\
\hline & & -0.6830585 & 1.009062 & 0.01987549 \\
\hline \multirow[t]{5}{*}{ LM } & pool_test & $\mathrm{P}$ & mp_test & Model.C \\
\hline & $\mathrm{Pa}$ & -0.8846697 & ta & 0.9690139 \\
\hline & $\mathrm{Pb}$ & -0.8094908 & tb & 0.9642517 \\
\hline & & PMSB & rhol & Pool.ADF \\
\hline & & -0.6829646 & 1.009062 & 0.01987549 \\
\hline
\end{tabular}

Note: these tests were carried out with PANICr module. 